\title{
The Upper Devonian of the river Sil area: a stratigraphic correlation between León and Asturias, northern Spain
}

\author{
G. B. S. van Loevezijn(1) and J. G. M. Raven ${ }^{(2)}$ \\ (1) Author for correspondence: Jan Sluijtersstraat 7, 3443 HP Woerden, The Netherlands. \\ (2) Naturalis Biodiversity Center Leiden, The Netherlands \\ stratpal.ger@gmail.com; han.raven@naturalis.nl.
}

\begin{abstract}
We have studied the Upper Devonian succession of the river Sil area divided into five sections along a SW-NE transect. Thirteen lithofacies types have been identified based on lithology and sedimentological structures. They have been organised into facies associations representing depositional environments from the fluviomarine zone of the nearby part of the basin towards the distal offshore zone. Erosion surfaces and sequence boundaries have been identified and the succession is connected to the Upper Devonian sequence stratigraphic model of the southern Cantabrian Mountains and the Upper Devonian succession of the Coastal Ranges of Asturias in the north. The main portion of the Upper Devonian succession of the Sil area can be correlated with the Nocedo Formation, Gordón Member (sequence A) of early Frasnian age. In the south-westernmost sections of the Sil area parts of the Fueyo and Ermita formations are exposed; they constitute sequence $\mathrm{C}$ of early Famennian age. The Upper Devonian Unconformity separates these thick Frasnian-Famennian coarsening upward sequences from the overlying extensive Famennian-Tournaisian condensed succession of the Llombera Beds (sequence D).
\end{abstract}

Keywords: Cantabrian Mountains, depositional history, facies, sequence stratigraphy, Upper Devonian.

\section{El Devónico Superior del área del rio Sil: una correlación entre León y Asturias, norte de España}

RESUMEN

La sucesión del Devónico Superior del área del rio Sil ha sido estudiada en cinco secciones a lo largo de un transecto SO-NE. Basándonos en la litología y las estructuras sedimentarias se diferencian trece litofacies. Éstas están organizadas en asociaciones de facies representando ambientes deposicionales que van desde fluviomarinos en la parte próximal de la cuenca hasta marinos de plataforma (offshore) la zona distal. Se identifican superficies erosivas y límites de secuencia y se compara la sucesión con el modelo de secuencias estratigráficas del Devónico Superior de la parte meridional de la Cordillera Cantábrica y de la costa asturiana del cabo Peñas. La mayor parte de la sucesión del Devónico Superior del área del Sil se puede correlacionar con la secuencia A del Miembro Gordón de la Formación Nocedo, de edad Frasniense. En las secciones del extremo suroeste del área del Sil parte de las formaciones Fueyo y Ermita constituyen secuencia $C$, de edad Famenniense. La Discontinuidad del Devónico Superior separa las secuencias granocrecientes $A$ y $C$, de gran espesor, de la superpuesta fina y condensada secuencia de las Capas de Llombera (secuencia D) de edad Fameniense-Tournaisiense.

Palabras clave: Cordillera Cantábrica, historia deposicional, facies, estratigrafía secuencial, Devónico Superior. 


\section{VERSION ABREVIADA EN CASTELLANO}

\section{Introducción y Metodología}

El área del Sil está localizada en la parte suroeste del dominio devónico Astur- Leonés de la Zona Cantábrica. En esta área, el Devónico Superior está principalmente constituido por areniscas, muy similares a las areniscas de la Fm. Piñeres de la costa del Cabo Peñas (García-A/calde, 1978; Raven, 1983) (Fig. 1). Varias subdivisiones de la sucesión estratigráfica del área del Sil han sido propuestas (Van den Bosch, 1969; García-Alcalde, 1978; Van Loevezijn y Raven, 1984; Van Loevezijn, 1986).

Sin embargo, la escasez de fósiles y la falta de contrastes litológicos de la monótona sucesión areniscosa, dificulta la datación precisa de estos depósitos y excluye, hasta ahora, una correlación definitiva con las lutitas $y$ areniscas de sectores situados más al sur (Figs. 3, 4).

Recientemente, un modelo de estratigrafía secuencial fue introducido para el Devónico Superior del sector sur de la Cordillera (Van Loevezijn y Van Loevezijn Peña, 2017). El objetivo de este trabajo es triple: primero, establecer en detalle la conexión estratigráfica entre la Formación Piñeres de la costa y la secuencia ya establecida en la vertiente sur, aportando la estratigrafía secuencial del área transicional del Sil; en segundo lugar, correlacionar las sucesiones existentes en la vertiente sur de la Cordillera Cantábrica, y finalmente, reconstruir las etapas deposicionales del Devónico Superior en el área del Sil.

El marco estratigráfico se ha establecido mediante el estudio de campo de cinco secciones situadas a lo largo de un transecto suroeste-noreste en el área del Sil. La descripción de las facies y su interpretación se han hecho siguiendo los procedimientos normales con especial atención en las estructuras sedimentarias.

El modelo estratigráfico secuencial del Devónico Superior de la vertiente sur de la Cordillera Cantábrica contiene un total de cuatro límites de secuencia (sb1 hasta 4), representados por desplazamientos en la sedimentación a facies más profundas no adyacentes y/o episodios erosivos (Van Loevezijn y Van Loevezijn Peña, 2020) (Fig. 14). Estos autores han dividido los depósitos frasnienses de la Formación Nocedo en dos secuencias somerizantes: la secuencia A del Miembro Gordón y la secuencia B del Miembro Millar. Las pizarras de la Formación Fueyo y las areniscas de la Formación Ermita, ambas de edad Fameniense, integran la sucesión somerizante de la secuencia C. Sobre ellas, la delgada sucesión de grano grueso de las Capas de Llombera y las calizas arenosas con crinoideos de la Formación Baleas, se incluyen en la secuencia D. En la costa de Asturias, al Devónico Superior se denomina Formación Piñeres y a las calizas con crinoideos superiores, Formación Candamo (Figs 3, 5). Trece tipos de litofacies se han diferenciado en el área del Sil según la litología y estructuras sedimentarias (Figs 6, 7).

\section{Correlaciones}

Las secciones de Lumajo (Fig. 8), La Cueta (Figs 11, 12) y Meroy (Fig. 13) muestran arquitectura estratigráfica similar y contienen un total de dos límites de secuencia: la primera, localizada en la base, entre los depósitos arrecifales de la Formación Portilla y los siliciclásticos superpuestos de la Formación Nocedo, puede correlacionarse con la sb1 del área del Bernesga. Sobre dicha discontinuidad, la asociación de facies se organiza en una secuencia granocreciente $y$ somerizante, con un tramo carbonatado en la parte inferior, de forma muy similar a la secuencia de facies del área del Bernesga, con evolución gradual desde lutitas de plataforma (offshore) o de transición, hasta areniscas sublitorales (shoreface), sin la presencia de ritmitas de areniscas y lutitas originadas por tormentas (Figs 14, 15). La correlación con la secuencia A restringe la sucesión del Devónico Superior del área del Sil situada bajo el segundo límite de secuencia a las zonas de conodontos valsiovalis Sup., hassi Inf, y hassi Sup. (Van Loevezijn y Van Loevezijn Peña, 2017). Ello está en concordancia con la fauna de braquiópodos de edad Frasniense existente en la parte media de la sucesión (García-Alcalde, 1978). Las areniscas lutíticas intercaladas en la parte inferior de la sección del Puente de las Palomas se atribuyen a la Formación Fueyo (Fig. 9). Sobre ellas se sitúan las cuarcitas con estratificación cruzada de la Formación Ermita (Fig. 10). Ambas unidades forman parte de secuencia $C$ del modelo estratigráfico secuencial del Devónico Superior elaborado por Van Loevezijn y Van Loevezijn Peña (2017). La segunda superficie límite en el área del Sil es claramente erosiva y separa la secuencia $A$ de la sucesión superior constituida por 24-28 m de areniscas microconglomeráticas con herringbone, conglomerados y calizas. Esta superficie límite erosiva puede correlacionarse con la discontinuidad sb4, entre las areniscas del Devónico Superior y los sedimentos de grano grueso correspondientes a las Capas de Llombera en el área del Bernesga (Fig. 16). Hacia el núcleo de la Zona Cantábrica el proceso erosivo incrementó, y así, en la sección de Torrestío, la Discontinuidad del Devónico Superior excavó un relieve de hasta $20 \mathrm{~m}$ en las calizas givetienses de la Formación Portilla, estando rellena la topografía kárstica de areniscas ferruginosas microconglomeráticas del Devónico Superior (Fig. 15).

La Formación Piñeres en la sección de la playa de la Gargantera de la costa asturiana, está integrada por dos secuencias (Fig. 17). La inferior constituye una sucesión somerizante de facies, en la que de forma gradual se pasa desde lutitas de transición en la base, hasta areniscas de playas en el techo, sin presencia de capas de tormentas (Fig.18). El modelo y su posición estratigráfica sobre los depósitos arrecifales givetienses es similar a la secuencia $A$ de las áreas 
del Sil y Bernesga. La alternancia de lutitas-areniscas que se superponen en esta área de la costa asturiana, constituida por una potente sucesión de tempestitas de carácter somerizante (Van Loevezijn, 2020), debe corresponder a parte de la secuencia Fameniense $B$ o de la secuencia $C$. Provisionalmente, en este estudio se correlacionan con la secuencia $B$ por su posición estratigráfica, inmediatamente sobre la A (Fig. 19).

El modelo deposicional de la secuencia A muestra transiciones graduales de las facies, con lutitas (FT11) y lutitas bioturbadas (FT9) de zonas de transición, que gradan a arenas de facies sublitoral inferior (FT8, FT7), con desarrollo local de bancos carbonatados (FT6). La sucesión continua con extensos depósitos sublitorales (FT5), playas (FT4) y llanuras de marea (FT3) (Fig. 20). En el área del Sil, los depósitos de la secuencia $B$ no afloran. El modelo deposicional de la secuencia $C$ contiene una sucesión cuyos depósitos evolucionan desde capas de tormenta distales (FT10), a sublitoral inferior con arenas limosas, FT7, FT8), sublitoral superior con areniscas con estratificación cruzada (FT5), a fluviomareales representados por arenas gruesas y microconglomerados (FT4), y canales conglomeráticos fluviomarinos de llanura mareal arenosa (FT1) (Fig. 21). La secuencia $D$ contiene una sucesión muy delgada de carácter condensado con superficies de hardgrounds, erosión y mineralización (García-López y Sanz-López, 2002a; Van Loevezijn, 2020), con una zona de canales fluviomarinos proximales (FT1), carbonatos arenosos someros (FT6), y una zona fluviomareal distal, caracterizada por areniscas microconglomeráticas con estratificación cruzada (FT2) (Fig. 22).

\section{Historia deposicional del Devónico Superior en el área del Sil}

Los sedimentos frasnienses fueron acumulados en una cuenca sedimentaria marina con un perfil deposicional gradual con mayor profundidad en la Zona Externa (SW) de la cuenca Asturo-Leonesa (Fig. 23). Más tarde, en el Fameniense Inferior, el núcleo de la Zona Cantábrica y partes adyacentes de la cuenca Asturo-Leonesa, fueron levantados y erosionados, migrando el área deposicional hacia la Zona Externa, (SW) (Fig. 24). Durante el Fameniense Superior-Tournaisiense Inferior tuvo lugar un cambio deposicional desde una cuña clástica en la parte más externa de la cuenca Asturo-Leonesa, a una extensa plataforma marina ocupando el dominio previo del NE con erosión y exposición subaérea (Fig. 25).

\section{Conclusiones}

El flanco suroeste del sinclinal de la Vega de los Viejos contiene la sucesión más completa y potente del Devónico Superior del área del Sil. La secuencia A constituye una sucesión somerizante que va desde lutitas de plataforma (offshore) hasta areniscas sublitorales (shoreface). La secuencia B no está representada. La secuencia C está integrada por la cuña clástica somerizante de las formaciones Fueyo y Ermita. En la parte central del área del Sil, las secciones del Devónico Superior de son más delgadas y menos completas.

Estas series contienen dos superficies erosivas. La primera está localizada en la base de la Formación Nocedo y puede correlacionarse con la sb1 del área del Bernesga. La segunda aparece en la parte más alta de la serie y puede correlacionarse con la Discontinuidad del Devónico Superior sb4. La sucesión entre sb1 y sb4 se correlaciona con la secuencia $A$ en el área del Bernesga.

El tramo delgado superior, integrado por areniscas microconglomeráticas y areniscas canaliformes, constituye el techo del Devónico Superior en el área del Sil y puede correlacionarse con la serie condensada Fameniense-Tournaisiense de la secuencia $D$, representada por las Capas de Llombera y los $5 \mathrm{~m}$ de calizas arenosas encriníticas de la Formación Baleas. La mayor parte de las Areniscas de Piñeres de la costa asturiana se correlacionan con la secuencia A. El conjunto de alternancias areniscas lutitas que le suceden en la playa de la Gargantera, tentativamente se correlacionan con la secuencia $B$ del área del Bernesga por sus facies y situación sobre los materiales de la secuencia $A$.

\section{Introduction}

The Upper Devonian rocks of the Sil area constitute the transition between the fine-grained Upper Devonian of the southern mountain slope of León, and the coarser-grained development of the northern slope of Asturias (Fig. 1). Although the main part of the Sil area is situated in León, the Upper Devonian succession consists mainly of sandstones, and is very similar to the Upper Devonian Piñeres sandstone of Asturias in the north (García-Alcalde, 1978; Raven, 1983). Several Upper Devonian stratigraphic sub-divisions were proposed (Van den Bosch, 1969; García-Alcalde, 1978; Van Loevezijn and Raven, 1984; Van Loevezijn, 1986, Fernández et al. 2021). However, the scarcity of fossils hampers an accurate dating of these strata, and the lack of lithological contrast of the monotone sandstone succession so far precludes a conclusive correlation with the Upper Devonian shales and sandstone in the south. Sequence stratigraphy can resolve the correlation problem, allowing the introduction of sequences based on a sedimentological and sequence stratigraphical framework, and to use this as a correlation tool.

The essence of sequence stratigraphy is that sequence stratigraphic surfaces (sequence boundaries, maximum flooding surfaces, etc.) represent timelines and therefore it introduces a chronostratigraphic framework (Catuneanu, 2017). Recently a sequence stratigraphic model was introduced for the Upper Devonian mixed siliciclastic-carbonate succession of the southern Cantabrian Mountains (Van Loevezijn and Van Loevezijn Peña, 2017). Hence the goal of this 


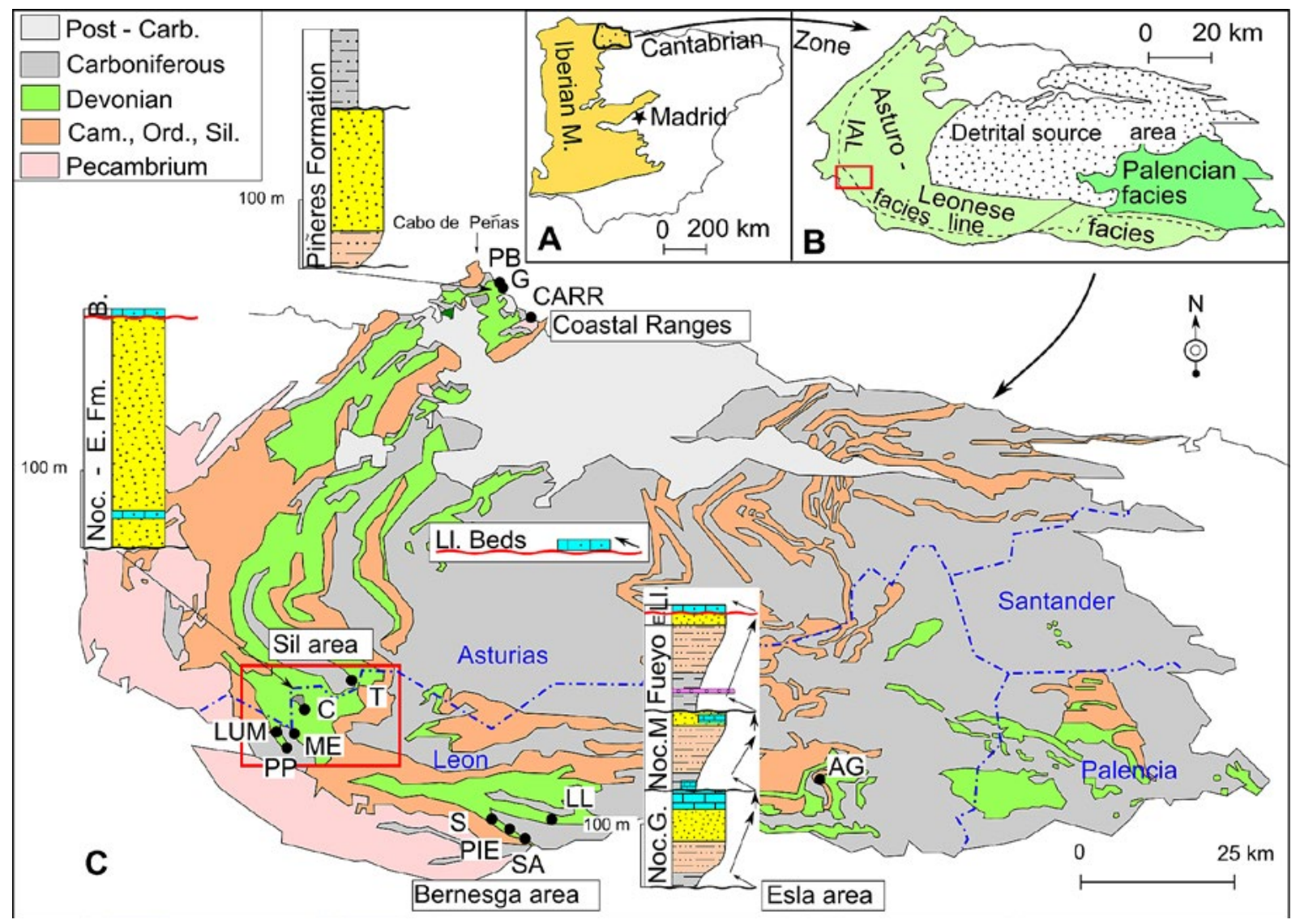

Figure 1. A) Situation map of the lberian Peninsula with the Cantabrian Zone. B) Map of the Cantabrian Zone with the major palaeogeographic units. C) Geological sketch map of the Cantabrian-Asturian arc with locations of the sections, changed after Herrero-Alonso et. al (2016). Red square corresponds to the Sil region in Figure 3; Noc. G = Nocedo Formation Gordón Member, Noc. M. = Nocedo Formation, Millar Member; E. = Ermita Formation, LI. = Llombera Beds. Abbreviations for the sections; LUM = Lumajo, PP = Puente de las Palomas, ME = Meroy, $\mathrm{C}=$ La Cueta, $\mathrm{T}=$ Torrestío, $\mathrm{S}=$ Saguera, PIE = Piedrasecha, SA = Soribos de Alba, LL = Llombera, AG = Aguasalio, PB = Playa de Boletos, $\mathrm{G}=$ Gargantera, CARR = Carranques.

Figura 1. A) Mapa de la Península Ibérica con la localización del Macizo Ibérico y la Zona Cantábrica. B) Esquema geológico de la Zona Cantábrica con las principales unidades tectonoestratigráficos. C) Mapa geológico de la Zona Cantábrica (modificado de Herrero-Alonso et al.,2016) con tres sucesiones tipo sintéticas de las regiones del Cabo Peñas, Sil (rectángulo rojo) y Bernesga. Claves de las unidades: G. = Miembro Gordón de la Formación. Nocedo, M. = Miembro Millar de la Formación Nocedo, E. = Formación Ermita, LI. = Capas de Llombera. Abreviaciones para las secciones: $L U M=$ Lumajo, $P P=$ Puente de las Palomas, $M E=$ Meroy, $C=$ La Cueta, $T=$ Torrestío, $S=$ Saguera, $P I E=$ Piedrasecha, $S A=$ Sorribos de Alba, $L L=$ Llombera, $A G=$ Aguasalio, $P B=$ Playa de Boletos, $G=$ Gargantera, $C A R R=$ Carranques .

study is threefold: first to analyse the Upper Devonian stratigraphical sequences of the Sil area, secondly to connect the established sequence stratigraphical model of the southern slope of the Cantabrian Mountains with the sequences of the Sil area and to correlate the succession to the Piñeres Formation in the north, and finally to reconstruct the Upper Devonian depositional stages of the Sil area.

\section{Methodology}

The stratigraphic framework of this fieldwork-based study contains the description of five outcrop sections along a SW-NE transect in the Sil area. Facies description and interpretation were performed following standard procedures with special attention to sedimentological structures. The sections were worked out in detail including the recognition of facies jumps and erosion surfaces, to identify the major bounding surfaces, and to analyse the facies stacks between the boundaries. Rock samples were studied in the laboratory, grain size and sandstone percentages analysed, and thin sections studied. The field work was carried out in 1980-1982 and 2019-2021. The grain sizes were classified according the Udden Wentworth scale, the sandstone was classified according to Dott (1964), and the limestone according to Dunham (1962) and Embry and Klovan (1972).

\section{Geological setting}

The Cantabrian Zone is an arc shaped Variscan foreland fold-and-thrust belt, also known as the Cantabrian Orocline, related to the closure of the Rheic Ocean and the collision between Laurussia and Gondwana (Gutierrez-Alonso et al., 2004; Pastor-Galán et 
al., 2013). It is situated in the northwestern area of the Iberian Peninsula, and is part of the Palaeozoic Iberian Massif (Lotze, 1945). The Cantabrian Zone is characterised by thin-skinned tectonics with a transport direction towards the core of the arc (Fig. 2). On the basis of stratigraphic and tectonic features, the Cantabrian Zone is sub-divided into several tectonostratigraphic regions or units (Julivert, 1971; Peréz Estaún et al., 1988; Alonso et al., 2009): the fold and nappe area, the Pisuerga-Carrión area, the Picos de Europa, the Ponga nappe area, and the Central Coal Basin. The study area is located in the fold and nappe area on the outer edge of the Cantabrian Arc.

The Cantabrian Zone contains a fairly complete, non-metamorphic to anchimetamorphic, Palaeozoic succession. It can be divided into a pre-orogenic Cambrian to Devonian succession and a Carboniferous synorogenic succession (Marcos \& Pulgar 1982).

The pre-orogenic deposits consist of shallow marine siliciclastics and carbonates that are thought to have been deposited on a stable platform on the northern Gondwana margin (Stampfli et al. 2013, Pastor-Galán et al., 2013). The succession thins towards the core of the Asturian Arc, forming a depositional wedge (Fig. 2c). The transition from pre-orogenic to synorogenic deposition took place during the end of the Devonian (García-Ramos and Colmenero, 1981; Keller et al., 2008). The Upper Devonian clastic deposits of the outer rim of the Cantabrian Zone are interpreted as the transitional tectono-sedimentary environment between the Devonian passive margin stage with extensive stable shelves, and the carboniferous synorogenic succession (Van Loevezijn, 2020). The widespread Upper Devonian unconformity and the overlying transgressive thin succession of coarse-grained sandsto- ne and limestone mark the fundamental reorganisation of the depositional system to Variscan sedimentation.

The condensed Mississippian succession is interpreted as the initial starved foreland basin-fill (Kullmann and Schönenberg, 1975; Keller et al., 2008). During the Pennsylvanian the Cantabrian Zone became an overfilled foreland basin in front of the advancing orogen, and a thick clastic wedge of synorogenic deposits were made up of deep-water sediments, carbonates and deltaic deposits (Marcos and Pulgar, 1982; Matte, 1991; Martín-Merino et al., 2014). These sediments are interpreted to have originated from the erosion of the internal zones of the Variscan Orogen in the southwest which gradually extended their influence on the deposition in an eastward direction, filling the foredeep trough. The advance of the deformation towards the foreland led to the development of Westphalian thin-skinned thrust-sheet imbricated nappe structures. The Westphalian sedimentation was mainly synchronous with the deformation and tectonically controlled wedge-top piggy-back basins developed related to the emplacement of the different thrusts (Martín-Merino et al., 2014). By the end of the Carboniferous the Cantabrian Zone had reached its definitive tectonic organization.

\section{Devonian Palaeogeographic units}

Several pre-Variscan palaeogeographic features controlled the Devonian depositional history.

The facies area of the Devonian Asturo-Leonese Basin (Brouwer, 1964), located in the fold and nappe area, is characterised by a shallow marine shelf succession, with a systematic change towards more proximal depositional environments, and less continuous successions toward the core of the Cantabrian Zone (Fig. 1b). The

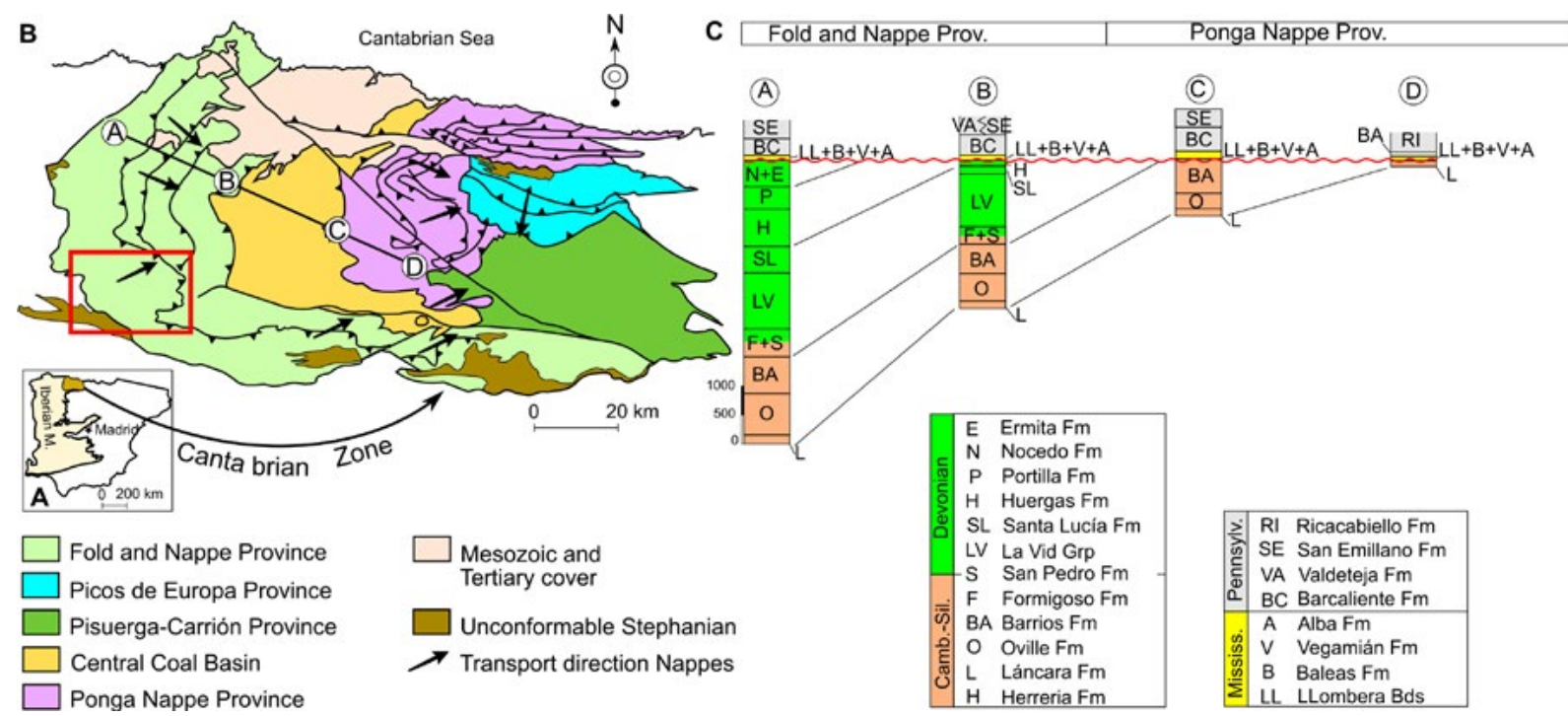

Figure 2. A) Schematic map showing the location of the Cantabrian Zone B) Schematic geological map showing the main tectonostratigraphic units of the Cantabrian Zone, and the transport directions of the nappes (Julivert, 1971; Alonso et al., 2009) C) Stratigraphic colums in the different tectono-stratigraphic units (changed after Alonso et al., 2009). Red square indicates location of study area.

Figura 2. $A$ y B) Esquema geológico de la Zona Cantábrica con las unidades tectonoestratigráficas y direcciones de transporte de las mismas (Julibert, 1971). C) Columnas sintéticas de las diferentes unidades (mod. de Alonso et al.,2009). Rectángulo rojo= área estudiada. 
core was an area of uplift and erosion, characterised by the near-complete absence of Silurian-Devonian strata, and the source of the surrounding sedimentation basin (Sjerp, 1967; Van Adrichem Bogaert, 1967).The Devonian pelagic Palencian facies is located in the Pisuerga-Carrión area in the east, and is considered allochthonous, representing the deeper south (western) continuation of the Asturo-Leonese Basin (Frankenfeld, 1984). In the outer part of the Asturo-Leonese Basin the Intra-Asturo-Leonese facies line (IAL facies line) separates the External Zone with a thick and continuous Upper Devonian succession in the southwest, from the northeastern area with a thin and incomplete Upper Devonian succession (Fig. 1b) (Sánchez de la Torre et al., 1977; García-Ramos and Colmenero, 1981; Raven, 1983; Van Loevezijn, 1986).

The Upper Devonian of the Sil area is located in the southwestern part the Asturo-Leonese facies area (Figs $1 b, 1 c)$. Its present-day geographical position on the border between León and Asturias is also known as the 'Asturian Knee', indicating a change in structural trend, where thrust and fold axes of the curved orogen of the Cantabrian Zone change from an E-W direction of the southern Leonese part of the Cantabrian Mountains to the N-S direction of Asturias (Fig. 1c). The area is covered by the 1:50000 map of Van den Bosch (1969) and by the 1:50000 IGME maps 101 Villablino (Vázquez, 1978), and 76 Pola de Somiedo (Rodríguez Fernández, 1979). The Sil area is dominated by three synclinal structures: the southwestern Palomas or La Vega de los Viejos syncline, the middle Quejo or La Cueta syncline, and the northeastern Saliencia syncline (Fig. 3).

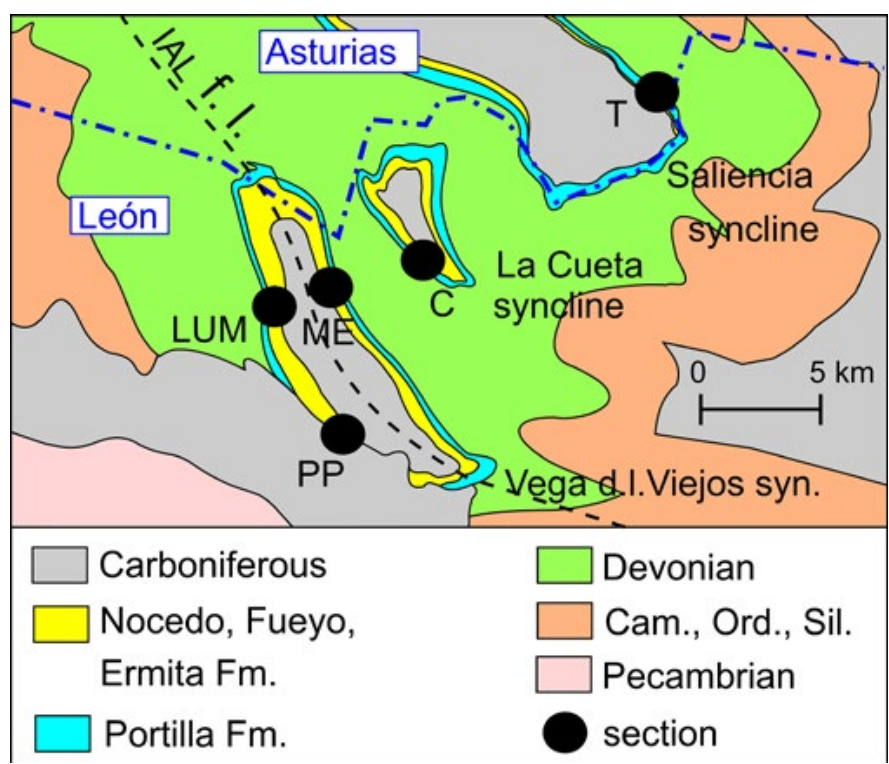

Figure 3. Schematic map of the Sil area showing the main synclinal structures, and the location of the sections. IAL f. I. = Intra Asturo Leonese facies line, $\mathrm{PP}=$ Puente de las Palomas, LUM = Lumajo, ME = Meroy, $\mathrm{C}=$ La Cueta, $\mathrm{T}=$ Torrestío.

Figura 3. Mapa geológico esquemático del área del Sil, con localización de los principales sinclinales y secciones estratigráficas estudiadas. IAL f.1. = Linea de facies Intra Astur- Leones, $P P=$ Puente de las Palomas, $L U M=$ Lumajo, $M E=$ Meroy, $C=$ La Cueta,$T=$ Torrestío.

\section{Upper Devonian stratigraphic units}

The Devonian stratigraphy of the Asturo-Leonese facies was described by Barrois (1882) in the northern slope of the Cantabrian zone (Asturias), and by Comte (1959) in the southern slope (León). These authors used different nomenclatures for the two areas. Although one name would be sufficient for each lithological equivalent, the different names between Asturias and León are still currently used and are widely accepted. As can be expected there are also lateral lithological changes between the northern and southern slopes which cover a present-day distance of up to $100 \mathrm{~km}$. These lateral changes occasionally complicate the correlation between the areas (Fig. 5).

The siliciclastic Upper Devonian in the south overlies the Givetian reef deposits of the Portilla Formation. It consists of the calcareous sandstone of the Nocedo Formation of Frasnian age, and the shales of the Fueyo Formation, and the sandstone of the Ermita Formation, both of Famennian age (Comte, 1959) (Fig. 4).

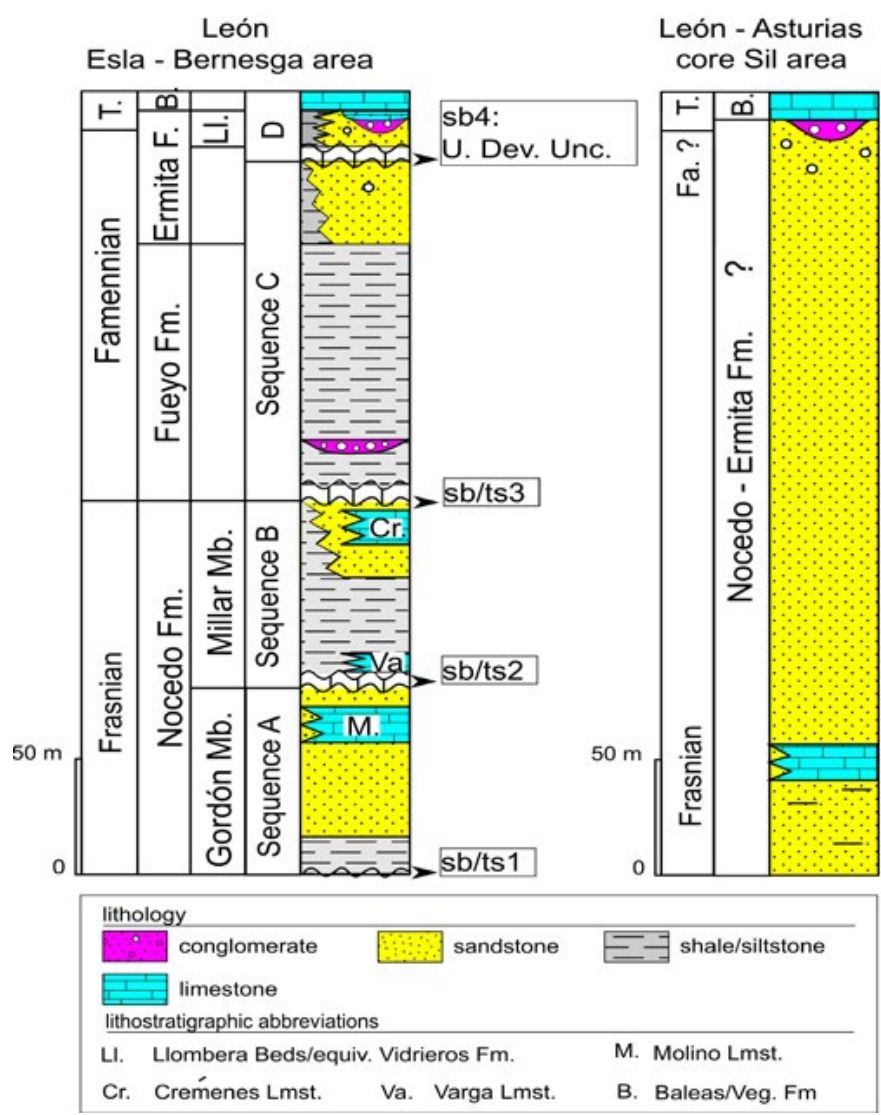

Figure 4. Upper Devonian stratigraphic subdivision of the Esla-Bernesga and Sil areas, with the sequence boundariestransgressive surfaces (sb/ts) indicated after Van Loevezijn (2020). $\mathrm{Fa}$. = Famennian.

Figura 4. Subdivisiones estratigráficas del Devónico Superior en las áreas del Bernesga y Sil, con los límites de secuencias transgresivas (sb/ts) según Van Loevezijn (2020). Fa. = Famenniense. 
The Givetian-Frasnian boundary is situated close to the base of the Nocedo Formation (García-López and Sanz-López, 2002a). The Frasnian Nocedo Formation ranges in thickness between $80 \mathrm{~m}$ and $450 \mathrm{~m}$, and is sub-divided into a lower Gordón Member and an upper Millar Member, each containing a shale-sandstone coarsening upward succession with a limestone unit on the top: the Molino limestone in the Gordón Member and the Crémenes limestone in the Millar Member. Locally, at the base of the Millar Member another limestone occurs, the Varga limestone (Van Loevezijn and Raven, 2017). The overlying, maximum $300 \mathrm{~m}$ thick shale succession of the Fueyo Formation is of Famennian age, and grades upward into the silty sandstone of the Ermita Formation with a thickness of up to $96 \mathrm{~m}$. It is truncated by the Upper Devonian Unconformity. Towards the NE, the unconformity represents deeper erosion, and in the core of the Cantabrian Zone it cuts down to Cambrian strata (Fig. 2c). Above there is a maximum $10 \mathrm{~m}$ thick succession of sand, conglomerate and coarse limestone, which form the Llombera Beds. The Devonian-Carboniferous boundary is located within these beds. The Llombera Beds are overlain by a thin-bedded crinoidal limestone unit, the Baleas Formation, or by theTournaisian black shales of the Vegamián Formation (Wagner et al., 1971). The limestone intercalations of the Llombera Beds and the overlying limestone of the Baleas Formation are similar in lithology and facies, which makes differentiation between the two difficult (Raven, 1983).

In the northern part of the Cantabrian Mountains along the Asturian coast the Upper Devonian is exposed in the Cabo Peñas area of the Coastal Ranges, with a thickness of more than $390 \mathrm{~m}$ in the westernmost section (playas de Boletos, Gargantera), to 22-78 $\mathrm{m}$ in the east (playas de Carranques, Perán, Piñeres). The equivalent of the Portilla Formation is known as the Candás Formation. Radig (1961) introduced a new unit for the overlying Upper Devonian siliciclastic succession, the Piñeres Formation (Fig. 1c). The uppermost metre of the Candás Formation contains conodont faunas representing the early Frasnian (García-López and Sanz-López., 2002b), therefore in the coastal ranges the boundary between the Candás limestone and the overlying Piñeres Formation is close to the Givetian-Frasnian boundary, but apparently slightly younger than in León. In this study the Piñeres Formation in Asturias is used as the equivalent of the Nocedo, Fueyo and Ermita formations in León sensu Truyols et al. (1990). In the Sil area, the Devonian nomenclature of Comte (1959) will be used. The Upper Devonian is mainly composed of sandstone with local (minor) intercalations of shale, limestone and conglomerate. Fossils are scarce. Conodont faunas in the lower part of the Upper Devonian succession indicate early Frasnian (Van Loevezijn, 1986; García-López and Sanz-López, 2002b). A pre-Famennian brachiopod fauna occurs in the Upper Devonian sandstone in the Vega de los Viejos syncline below the Upper Devonian Unconformity (sample PF1-
1P in Fernández et al., 2021). The uppermost part of the succession could be Famennian in age, although the scarcity of fossils hampers an accurate dating of these strata. Figure 5 shows the stratigraphic units in the different areas and the abbreviations used in this paper.

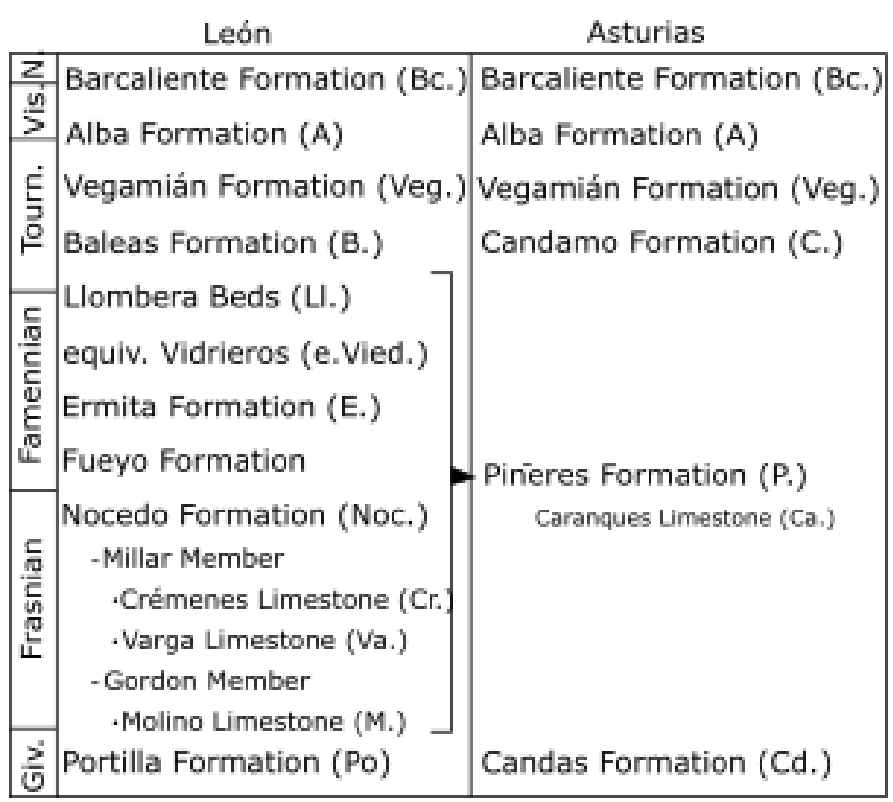

Figure 5. Names and abbreviations of the stratigraphic units in the different areas.

Figura 5. Nomenclatura de las unidades litoestratigráficas en las diferentes áreas.

\section{Upper Devonian facies types}

The Upper Devonian lithology changes from fine grained sediments in the Bernesga area in the south towards coarser successions, almost without fine sediments, in the Sil area. Therefore, the existing Upper Devonian lithofacies types of the Bernesga and Esla areas (Van Loevezijn and Van Loevezijn Peña, 2017; Van Loevezijn and Raven, 2017, 2020) were adapted to reflect the coarser successions of the Sil area, and a few new facies types were introduced. Because of the sandstone dominance and the lack of fossils, Upper Devonian facies types of the Sil area are exclusively based on lithology and sedimentological structures. From each facies type a description and a short interpretation is given. For a more detailed sedimentological discussion, the reader is referred to the references given. The facies types of the Sil area are summarised in Figure 6.

\section{FT1: Conglomerate facies}

Description: The discontinuous conglomerate beds constitute shallow, 5 to $10 \mathrm{~m}$ wide, erosive channel structures cutting down into the underlying pebbly sandstone facies. The conglomerate contains rounded quartzite pebbles up to $6 \mathrm{~cm}$ in 


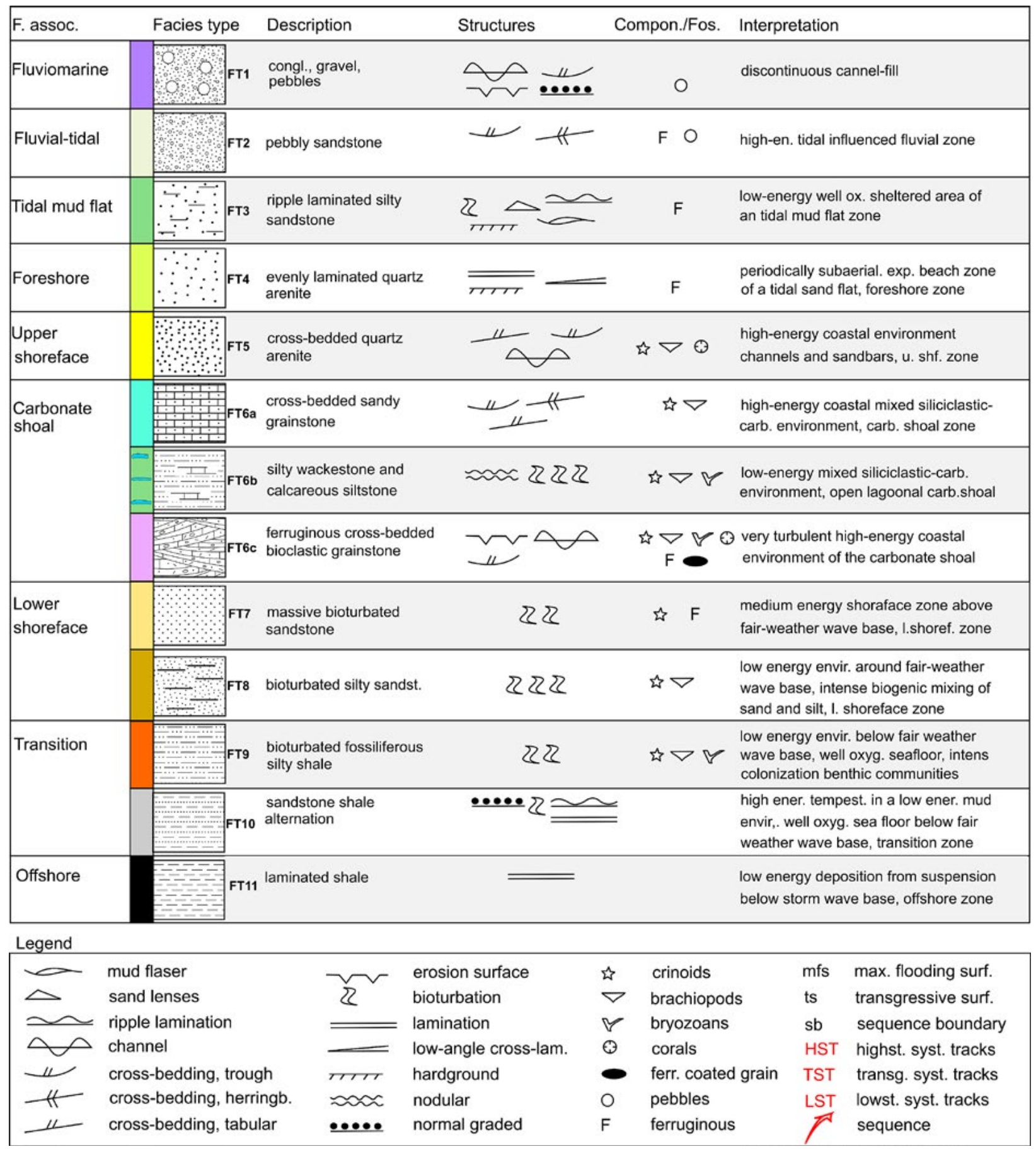

Figure 6. Upper Devonian facies types and facies associations of the Sil area.

Figura 6. Tipos y asociaciones de facies del Devónico Superior en el área del Sil.

diameter. The sediments are organised in undulating erosive beds, with a lateral pinch-out geometry. Fossils are absent. Locally the conglomerate moves upward to very coarse-grained sandstone, and is overlain by a sandy grainstone bed or coarse-grained sandstone.

Interpretation: The rounded quartz pebbles and the absence of fine sediments represent a high energy environment with turbulent conditions (Nichols, 2009). The pinch-out geometry of the wedge-shaped bed forms, and the erosive lower surfaces of the beds indicate channelised sediment bodies cutting down into the underlying sediment. The channels formed a network of fluviomarine channels and incised valleys, located between the detrital source area in the NE and the depositional area in the SW. 


\section{FT2: Pebbly sandstone facies}

Description: This facies type consists of medium to coarse-grained quartz arenites with pebbles of up to $1 \mathrm{~cm}$. Shales, silts and fine-grained sand do not occur. The sediment locally contains an iron-stained red colour grading to light grey. Tabular and trough cross-bedded sets, locally arranged in herringbone structures occur. The facies is intercalated in the top of the Upper Devonian succession and locally rests with a sharp erosive contact on the underlying sandstone succession

Interpretation: Herringbone structures are a diagnostic feature of the fluvial-tidal zone of river to coastal plain estuary (Gosh et al., 2006; Van den Berg et al., 2007). The virtual absence of clay drapes and fine sediments is explained by fluvial avulsion in these tidally influenced deposits.

\section{FT3: Ripple laminated bioturbated silty sandstone fa-} cies

Description: This facies type consists of grey brown, evenly laminated and ripple laminated very fine to fine-grained sandstone arranged in 20 to $60 \mathrm{~cm}$ thick beds with a few cross-beds, alternating with mud intervals with sand flasers and thin, up to $10 \mathrm{~cm}$ thick, sandstone beds. The asymmetrical ripple structures contain bifurcating, regular crests. Locally, the sediment is completely burrowed. This facies is intercalated within the quartz arenites of (FT4), and-(FT5).

Interpretation:The fine-grained sediment and the intercalation between shoreface and foreshore deposits indicate low energy depositional conditions close to the coast, partly sheltered from the high energy coastal environment; the sheltered zone of a tidal flat, with a low to mid tidal range (Reineck and Singh, 1975; Reinson, 1979).

\section{FT4: Fine to medium-grained evenly laminated quartz arenite facies}

Description:This facies type consists of white to light grey coloured, fine to medium-grained, evenly laminated and low-angle laminated quartz arenites. Bioturbated banded ferruginous mineralisation surfaces occur frequently (Van den Bosch, 1969; Van Loevezijn, 1986). They are strata bounded, and are characterised by (Van Loevezijn, 1986): (1) a limited thickness (0.5-2.5 m) and vast lateral extension; (2) red and violet colours becoming more intense from base to top; (3) topped by a haematite-bearing mottled shale crust; (4) a gradual transition of the lower boundary and a sharp upper boundary (Fig. 7). The laminated quartz arenites occur in the upper part of the Upper Devonian succession, and are intercalated between the cross-bedded quartz arenite strata below (FT5), and the pebbly sandstone (FT2) and conglomerate strata (FT1) above.

Interpretation: The pure well-sorted character of the quartz arenites, and the absence of matrix indicate deposition in agitated water above wave base. The laminations were formed by swash and back-swash ac- tivity in the foreshore zone (Reineck and Singh, 1975; Nichols, 2009). The laterally persistent bored ferruginous horizons were formed by periodical subaerial exposure of the sandflat area, where mud areas occurred between the sand ridges (Van den Bosch, 1969; Van Loevezijn, 1986).

FT5: Fine to medium grained cross-bedded quartz arenite facies

Description: This facies type consists of light-grey to white, fine to medium-grained ripple laminated and cross-bedded sandstone. Locally the silica cement transforms the sandstone to quartzite. The $10-70 \mathrm{~cm}$ thick beds contain well-developed bedding surfaces. Locally scarce mud drapes were observed between the pristine quartz arenite beds. Both tabular and trough cross-bedded sets occur. Bioturbation is almost absent. In the Meroy section moulds of coral, brachiopods and crinoid ossicles occur locally in the cross-bedded quartz arenites.

Interpretation: The mineralogical and textural mature sediment reflect a high-energy agitated water environment. Cross-bedded sets were formed by migrating bars and channels in the shallow marine area of the upper shoreface zone. This resulted in texturally mature sediment without almost any bioturbation structures (Reineck and Singh, 1975; Reinson, 1979; Nichols, 2009).

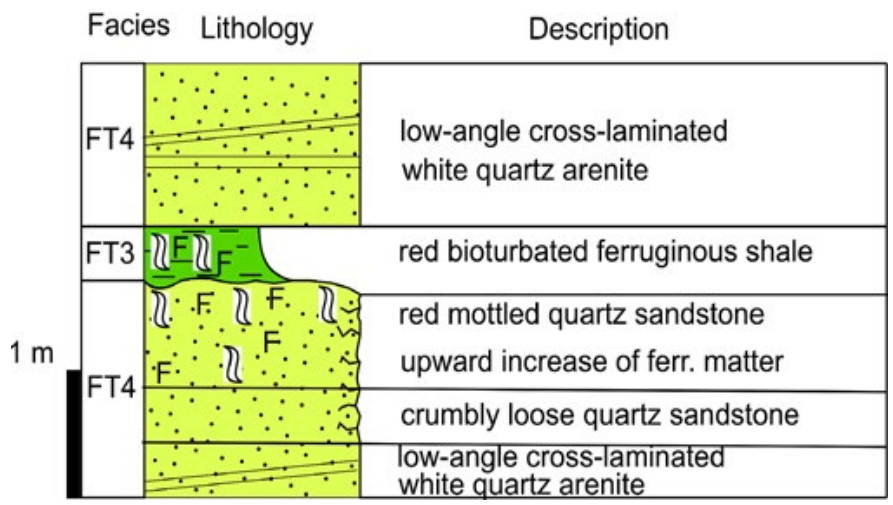

Figure 7. A completely developed ferruginous soil containing a ferruginous mineralisation surface and a rippled bioturbated mud bed (after Van Loevezijn, 1986).

Figura 7. Suelo ferruginoso bien desarrollado con superficie de mineralización de hierro y lutitas ondulantes bioturbadas. (basado en Van Loevezijn, 1986).

\section{FT6: Limestone facies}

This facies type occurs in the lower part of the Upper Devonian succession, close to the underlying Portilla Limestone Formation. The limestone facies consists of a mixture of carbonate and siliciclastic components, creating a variety of carbonate-siliciclastic combinations, with a gradual transition from siliciclastic dominated to carbonate dominated. Three limestone sub-facies can be distinguished: a sandy grainstone, a bioclastic grainstone, and a silty wackestone. 


\section{FT6a: Cross-bedded sandy grainstone}

Description: This facies type consists of grey, very-fine to fine-grained, cross-bedded sandy grainstone. The components of the grainstone consist of quartz grains, with occasionally brachiopod and crinoid bioclasts, cemented by calcite. The limestone is well developed in 20 to $70 \mathrm{~cm}$ thick beds. Most of the cross-bedding consists of tabular sets, locally arranged in herringbone structures. Some trough cross-bedded sets were observed. The facies type has a gradual contact with the calcareous sandstones of FT7 and the silty limestone of FT6b. Towards the silty limestone (FT6b) the texture changes from grainstone to packstone with small amounts of micrite, and shale lenses between the limestone beds. Between the calcareous sands of FT7 and the overlying sandy limestone of FT6a, an upward gradual increase of calcareous content can be observed in the sandstone.

Interpretation: The gradual transition to the massive sandstone facies (FT7) indicates deposition close the shoreface zone. The facies type represents a carbonate shoal environment that developed just above the lower shoreface zone, forming upper shoreface bars and submarine topographic highs, and resembles the sandy grainstone of facies type 2a of the Upper Devonian Molino Limestone in the Bernesga area (Van Loevezijn and Raven, 2017).

FT6b: Bioturbated silty wackestone and calcareous siltstone

Description: The facies consists of a grey-brown, nodular alternation of thin bedded silty wackestone and calcareous sandy siltstone and shale. Bryozoans, crinoids and brachiopods occur in large quantities. The sediment is heavily bioturbated and completely reworked, which has caused its nodular mixed appearance. This facies type has a gradual contact with the sandy limestone facies type (FT6a); close to the overlying sandy limestone the sandstone content gradually increases upwards, thus creating a gradual facies transition between F6a and FT6b.

Interpretation: The sediment indicates quiet water conditions with a high biological mixing and contains a close relation with the turbulent water environment of the carbonate shoal. We assume a semi-restricted environment, with a shoal sheltering it from the high energy environment (Remane and Schlieger, 1971; Schlager, 2005). The sediments resemble the silty wackestone of facies type 1a of the Upper Devonian Molino Limestone in the Bernesga area (Van Loevezijn and Raven, 2017).

\section{FT6c: cross-bedded bioclastic grainstone}

Description: This facies type consists of red to purple coloured ferruginous, coarse-grained cross-bedded bioclastic grainstone, with a variable amount of very-fine to fine-grained quartz sand. The well-developed beds are around $20-50 \mathrm{~cm}$ thick and have sharp, erosive surfaces. Most of the cross-bedding is devel- oped as trough shaped sets. The bioclastic content is characterised by the accumulation of large quantities of coarse echinoderm plates, crinoid ossicles, clasts of branching tabulate coral, brachiopods, bryozoans, and unidentifiable bioclasts.

Interpretation: The deposits indicate a turbulent agitated shallow marine environment in which sediment was reworked by powerful currents, with constantly shifting channels and bars. In this turbulent environment fines were easily washed out. The sediment resembles coarse-grained bioclastic grainstone of facies type 2c of the Upper Devonian Molino Limestone in the Bernesga area (Van Loevezijn and Raven, 2017), and are similar to the cross-laminated bioclastic packstone and grainstone of facies $\mathrm{C}$ of Burchette and Wright (1992), and the shoals and bank environment of the inner ramp setting of Flügel (2004).

\section{FT7: Very fine to fine-grained massive sandstone}

Description: Red coloured grading to brown coloured, locally ferruginous mottled, very fine to fine-grained massive quartz sandstone, arranged in up to 80 $\mathrm{cm}$ thick beds. Cross-bedding is uncommon. The sediment is medium bioturbated. Locally some moulds of crinoid ossicles can be observed. The lower part of the facies succession is slightly calcareous. The facies is underlain by the bioturbated siltstones facies (FT8) and overlain by the cross-bedded sandstone facies (FT5). Locally a (sandy) limestone succession of the carbonate shoal facies (FT6) is intercalated.

Interpretation: The absence of cross-bedded structures indicates deposition outside the upper shoreface zone of migrating longshore bars and shifting channels, close to the fair-weather wave base. The massive sandstone facies represents the lower part of the shoreface zone, a region composed of medium-bioturbated very-fine to fine-grained sand with minor amounts of ripple cross-bedding (Reineck and Singh, 1975; Nichols, 1999).

\section{FT8: Bioturbated silty sandstone}

Description: Brown coloured, calcareous, very fine-grained, nodular, thin bedded, silty quartz sandstone. The sediment is intensely bioturbated and completely reworked, resulting in nodular amalgamated bed forms.

Interpretation: The bioturbated silty sandstone has a gradual contact with the very fine-grained lower shoreface sandstones of FT7. The significant amount of silt in the sediment indicates deposition sea-ward of the main coastal sand area close to the fair-weather wave base, where very fine-grained sand and silt was mixed with a very intense biogenic reworking (Reineck and Singh, 1975; Nichols, 1999).

\section{FT9: Bioturbated silty shale}

Description: This facies type is exposed in the basal part of section La Cueta, where it rests on the reef deposits of the Portilla Limestone Formation, and in 
the middle part of section Lumajo. It consists of grey, bioturbated, fossiliferous, calcareous, nodular, 10-50 $\mathrm{cm}$ bedded siltstones grading to $1-10 \mathrm{~cm}$ bedded shales. The calcareous silty part contains large quantities of brachiopods. Crinoids and bryozoans also occur. In the Lumajo section a gradual transition can be observed between the laminated shales (FT11) and the overlying bioturbated silty shale (FT9). Upward the silty shale facies grades to silty sandstone (FT8), and calcareous sandstone (FT7).

Interpretation: The bioturbation and the abundance of brachiopods and crinoids require well oxygenated bottom water conditions. We consider a low energy environment, with a regular supply of silty sediment. The gradual transition to coastal sandstone suggests a close relationship with the shoreface environment. The sediments were deposited in the transition zone below the fair-weather wave base, where mainly silty sediment accumulates, and where the biogenic processes are dominant (Reineck and Singh, 1975; Nichols, 1999).

\section{FT10: Shale sandstone alternation}

Description: This facies type consists of a rhythmic alternation of grey brown, $8-30 \mathrm{~cm}$ thick, very finegrained sandstone beds and silty shale. The shalesandstone ratios range between 80-20 with thin-bedded sandstone successions, to 10-90 with sandstone beds up to $30 \mathrm{~cm}$ thick. Locally the intercalated mud layers are very thin or absent, and the sandstone beds are amalgamating at the erosional surfaces. Most of the sandstone beds have sharp, gently wavy, locally clearly erosive basal surfaces, and sharp top surfaces. They contain a structureless massive or even-laminated basal part, and a wave-ripple laminated upper half. The silty shale in between the beds is fairly bioturbated; locally completely reworked horizons occur. Soft sediment deformation structures can be observed in the thick bedded successions. This facies type is only observed in the Fueyo Formation of section PP in the southwestern part of the Vega de los Viejos syncline. The lower boundary of the shale-sandstone succession is mantled by Stephanian deposits, and the upper boundary of the FT10 succession is not exposed.

Interpretation: The internal structures of the sandstone beds resemble the sequence of sedimentary structures generated by storm waves (Dott and Burgeois, 1982; Walker and Plint, 1992). The interbedded sand layers are the result of deposition during heavy storms when high suspended sediment concentrations are introduced into the transition zone by offshore directed gravity flows. In between storms, clay and mud settled in the low-energy environment between the fair weather and storm weather wave bases (Myrow and Southard, 1996).

\section{F11: Laminated shale}

Description:This facies type mainly consists of pure grey-brown laminated shale. Locally in the shale suc-

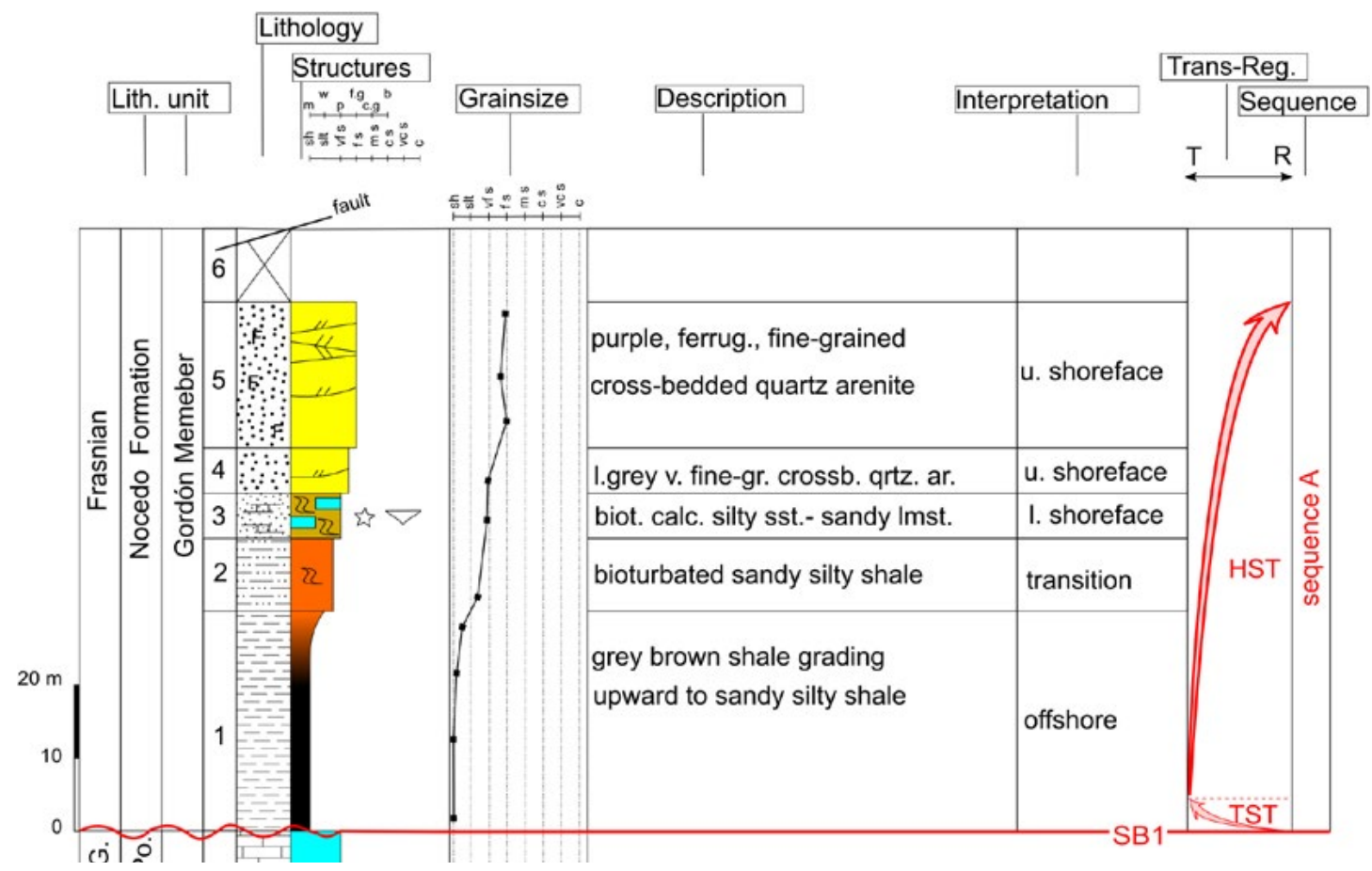

Figure 8. Log, grain size distribution, description, interpretation and sequence stratigraphy of the Lumajo section. Cd. = Candás Formation, Po = Portilla Formation. For legend see Figure 6.

Figura 8. Columna, distribución granulométrica, descripción, interpretación y estratigrafía secuencial de la sección de Lumajo. Cd. = Formación Candás, Po = Formación Portilla. (Leyenda en Fig. 6). 
cession a gradual introduction of silty sediment is observed. Bioturbation is low and this facies type has very few fossils. It only occurs in the western limb of the Vega de los Viejos syncline. It rests on the limestone of the Portilla Formation and is overlain by silty deposits of the transition zone (FT 9).

Interpretation: Cross-bedded structures are absent and no sand was introduced in this environment. The activity of the current was extremely weak. Sediments were slowly deposited out of suspension beyond the reach of the coastal sand supply, below the storm wave base in the outer shelf environment (Reineck and Singh, 1975; Nichols, 1999).

\section{Facies stacks}

The westernmost outer part of the Sil area contains the thickest Upper Devonian (Van den Bosch, 1969;

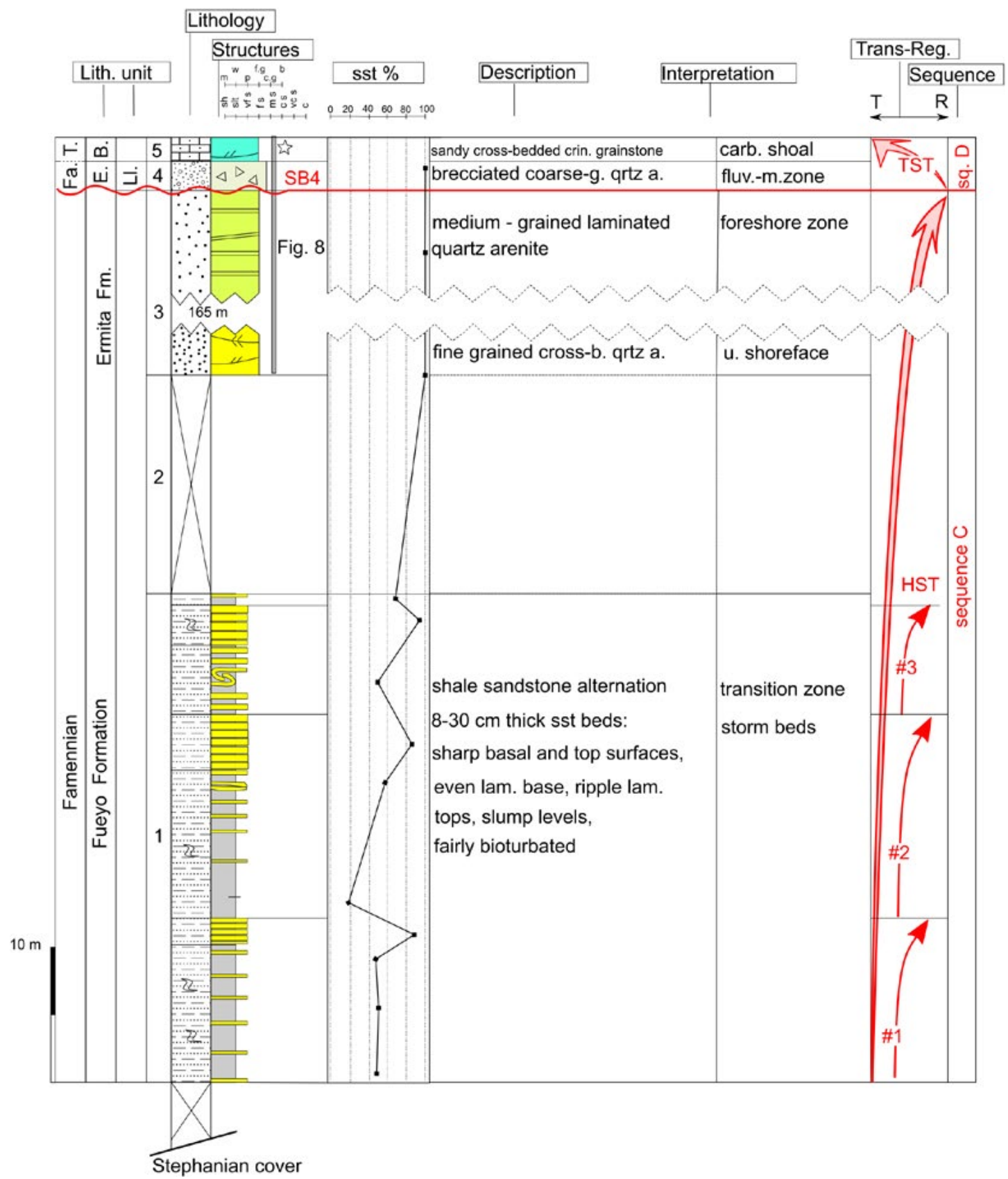

Figure 9. Log, grain size distribution, description, interpretation and sequence stratigraphy of the Puente de las Palomas section; LI. = Llombera Beds, E. = Ermita Formation, P. = Piñeres Formation, C. = Candamo Formation, B. = Baleas Formation. For legend see Figure 6. Figura 9. Columna, distribución granulométrica, descripción, interpretación y estratigrafía secuencial de la sección del Puente de las Palomas. LI. = Capas de Llombera, E. = Formación Ermita, P. = Formación Piñeres, C. = Formación Candamo, B. = Formación Baleas. (Leyenda en Fig. 6). 
Van Loevezijn, 1986). Two sections were measured, both located in the southwestern limb of the Vega de los Viejos syncline: one near the village of Lumajo, the other at Puente de las Palomas (Fig. 3). These sections are complicated by faults and only parts of the Upper Devonian are exposed. In the central part of the Sil area the Upper Devonian succession becomes slightly thinner and very sandy (Van Loevezijn and Raven, 1984). Two well exposed Upper Devonian sections are located there. One is situated in the northeastern limb of the Vega de los Viejos syncline along the road to Pola de Somiedo (Meroy section; Fig. 3). The second one is located in the southern nose of the La Cueta syncline along the east side of the road near Quejo ( $\mathrm{La}$ Cueta section; Fig 3). Towards the northeast, near the village Torrestío, a thin and incomplete Upper Devonian succession is exposed in the nose of the Saliencia syncline.

\section{Sil area; Lumajo section (LUM)}

Description: North of Lumajo the lower part of the Upper Devonian succession is exposed (Van den Bosch, 1969; Van Loevezijn, 1986) (Fig. 8). The base of the section, located near the village Lumajo consists of a $30 \mathrm{~m}$ thick succession of grey brown pure shale (FT11). The uppermost part becomes silty, grading to bioturbated silty and sandy shale. (FT9). Above it, $6 \mathrm{~m}$ of very calcareous bioturbated sandstone occurs, grading into sandy limestone, with brachiopods and crinoids (FT8), overlain by $6 \mathrm{~m}$ of cross-bedded very fine to fine-grained quartz arenites (FT5). The upper $20 \mathrm{~m}$ consists of purple coloured, poorly exposed cross-bedded ferruginous fine-grained sandstone with trough cross-bedding locally organised as herringbone structures (FT5). The top of the section is badly exposed and cut off by a fault. The overlying strata are partly exposed south of Lumajo near the old road to Puente de las Palomas (section PP).

Grain size distribution: The facies stack displays a very gradual coarsening upwards without spikes, from shale in the basal part, to silt followed by very fine-grained sand, with fine-grained sand at the top of the section.

Interpretation: The contact between the reefal limestone of the Portilla Formation and the overlying shale (FT11) of the Nocedo Formation represents a facies jump to offshore. Both the stepwise shallowing upward development from offshore to shoreface, without abrupt facies shifts, and the gradual coarsening upward grain size curve without major excursions, indicate a single, genetically related depositional cycle. The top of the section is cut off by a fault, therefore it does not display the complete cycle.

\section{Sil area; Puente de las Palomas section (PP)}

Description: In the western limb of the Vega de los Viejos syncline near the old mountain road between Puente de las Palomas and Villaseca, the upper part of the Upper Devonian succession is exposed (Van den
Bosch, 1969; Van Loevezijn, 1986). However, part of the Upper Devonian is covered by Stephanian deposits and the succession is complicated and disturbed by faults.

According to the Spanish IGME 50000 map nr 101, Villablino (Vázquez, 1978) the lower half of the Upper Devonian section in Van Loevezijn (1986) containing the Millar Member of the Nocedo Formation, must be interpreted as Stephanian. Only the upper half of the section can be attributed to the Upper Devonian (Van den Bosch, 1969). The section consists of several parts, exposed along the curves of the old road (Fig. 9). From the stratigraphic reconstruction a $38 \mathrm{~m}$ thick coarsening upward succession emerges, consisting of silty shale alternating with very fine-grained laminated graded sandstone beds (FT10) with slump levels and shallow channels (unit 1). The top of the shale-sandstone interbedded succession is not exposed (unit 2). Above $183 \mathrm{~m}$ of light grey quartz arenites occur (unit 3), with trough and tabular cross-bedded intervals (FT5), as well as even laminated and low-angle cross-bedded parts (FT4) (Fig. 10). Locally the quartz arenites are eroded by conglomerate intercalations (FT1). Above $3.8 \mathrm{~m}$ of brecciated pebbly sandstone occurs (FT2) (unit 4). The uppermost part of the section consists of $5 \mathrm{~m}$ cross-bedded sandy crinoidal grainstone (FT6a) (unit 5). Units 4 and 5 correlate with the $12 \mathrm{~m}$ of bioclastic and sandy limestone of section VV above the Upper Devonian Unconformity (sb4) in Fernández et al. (2021). However, they used a different stratigraphic nomenclature and named it the Ermita Formation; in this study the sandstone succession above the shale of the Fueyo Formation is known as the Ermita Formation (Comte, 1959) whilst the thin (course-grained) siliciclastic succession above the unconformity is called the Llombera Beds (Keller et al., 2008; Van Loevezijn and Van Loevezijn Peña, 2017).

Grain size distribution: The sand of the interbedded shale sandstone succession is very fine-grained. To investigate the overall grain size distribution, the sandstone percentages were logged. The facies stack displays a gradual coarsening upwards without major spikes, organised into three small-scale cycles, with values ranging around 20 for the basal part, to 90 in top of the section.

Interpretation:The gradual upward increase of the bed thickness and sand percentage of the storm-bedded succession of FT10 are indications of a gradual shallowing upward trend (Fig. 9). The overlying sandstone-conglomerate facies stack represents an upward facies change from shoreface to foreshore, with conglomerate channel intercalations. Above the sequence boundary sb4 the 3 to $4 \mathrm{~m}$ of brecciated pebbly sandstone of the fluvio-tidal zone occurs, overlain by the cross-bedded grainstone succession of the carbonate shoal zone (Fig. 10).

\section{Sil area; La Cueta section (C)}

This section is exposed in the Sil valley $500 \mathrm{~m}$ north of the village of Quejo, along the east side of the road 


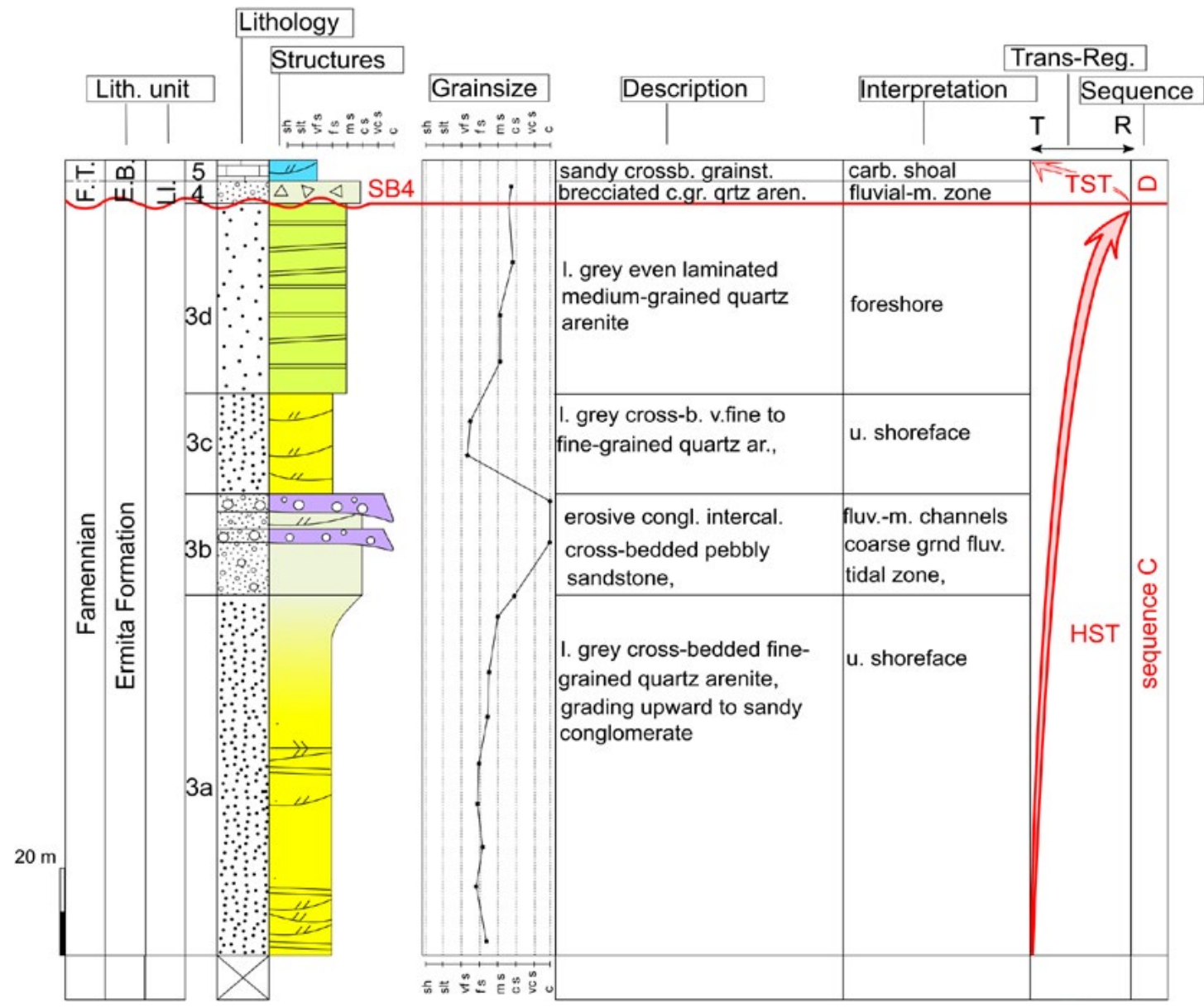

Figure 10. Detailed log of the upper part of section Puente de las Palomas in Figure 7. LI.= Llombera Beds, E. = Ermita Formation, P. = Piñeres Formation, C. = Candamo Formation, B. = Baleas Formation. For legend see Figure 6.

Figura 10. Columna detallada de la parte superior de la sección del Puente de las Palomas (Fig. 7). Ll.=Capas de Llombera, E. = Formación Ermita, $P$. = Formación Piñeres, C. = Formación Candamo, B. = Formación Baleas. (Leyenda en Fig. 6).

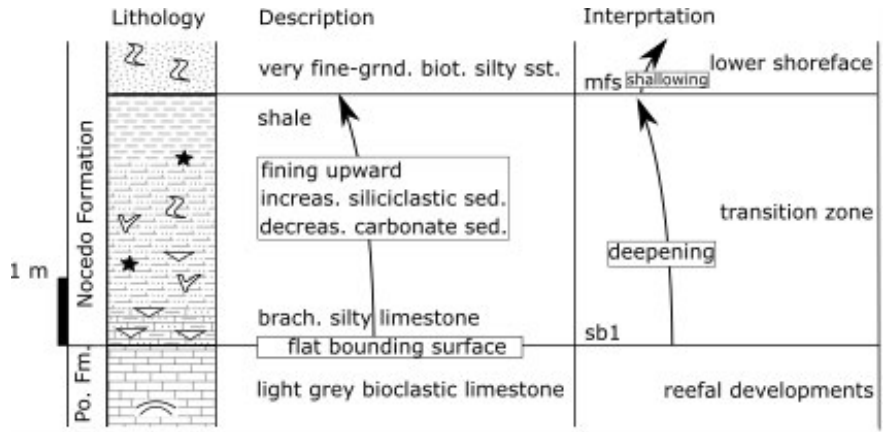

Figure 11. Description and interpretation of the contact between the Portilla Formation and the Nocedo Formation of the La Cueta section.

Figura 11. Descripción e interpretación del contacto en las formaciones Portilla y Nocedo en la sección de La Cueta.

to La Cueta (Fig. 3), in the southern nose of the La Cueta syncline.

Description: The contact between the reef limestone of the Portilla Formation and the Upper Devonian siliciclastic succession is a flat bounding surface (Fig. 11). The grey Portilla limestone is overlain by a gradual fining upward succession from brachiopodal calcareous siltstone to shale (Fig. 12: unit 1). Above a $10 \mathrm{~m}$ thick succession of bioturbated siltstone and fine-grained sandstone of FT7 and 8 occur (Fig. 12: unit 2). The fine-grained sandstone change upward to sandy grainstone (FT6a) of the mixed siliciclastic carbonate succession of unit 3 . Above the sandy grainstone, fossiliferous bioturbated silty wackestone and calcareous siltstone occur (FT6b), with two purple coloured coarse grained bioclastic intervals (FT6c). The section continues with $49 \mathrm{~m}$ of ferruginous sandstone, followed by $32 \mathrm{~m}$ of grey fine-grained quartz arenites (FT7) (units 4-8). The succession is overlain by $33 \mathrm{~m}$ of light-grey fine-grained cross-laminated quartz arenites (FT5) (unit 9), followed by $16 \mathrm{~m}$ evenly laminated and low-angle cross-laminated quartz arenites (FT4), containing bioturbated banded ferruginous mineralisation surfaces and rippled mud beds (FT3) (unit 10). The uppermost $18 \mathrm{~m}$ consist of course-grained quartz arenites and conglomerates with granules up to 0.5 $\mathrm{cm}$ (unit 11). Above $8 \mathrm{~m}$ of the unexposed section (unit 12), Namurian dolomites of the Barcaliente Formation are found. 


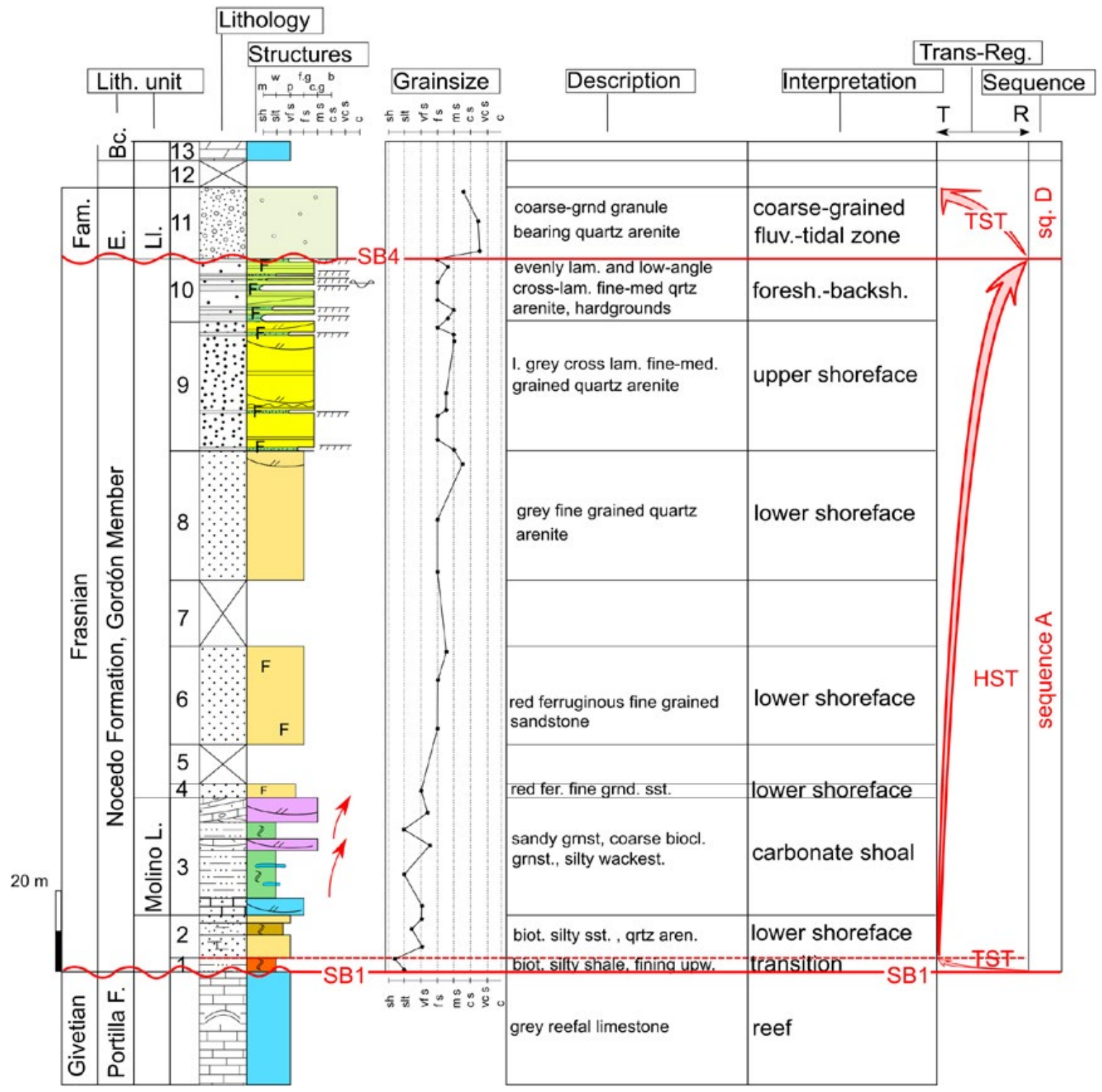

Figure 12. Log, grain size distribution, description, interpretation and sequence stratigraphy of the La Cueta section. P. = Piñeres Formation, E. = Ermita Formation, LI. = Llombera Beds, BC = Barcaliente Formation. For legend see Figure 6.

Figura 12. Columna, distribución granulométrica, descripción, interpretación y estratigrafía secuencial de la sección de La Cueta. $P$. = Formación Piñeres, E. = Formación Ermita, LI. = Capas de Llombera, BC. = Formación Barcaliente. (Leyenda en Fig. 6).

Grain size distribution: The sediments display a gradual coarsening upwards from very fine to fine-grained sand in the base of the section to fine-medium grained sand in the upper portion of the section without major excursions. The only grain size jump occurs $24 \mathrm{~m}$ below the top, where the ferruginous fine-grained sand is overlain by sandy conglomerates.

Interpretation: The facies stack indicates a gradual trend from transition zone to lower shoreface deposits (units 1,2) with carbonate shoals (unit 3), overlain by lower shoreface deposits (units 4-8), followed by upper shoreface deposits (unit 9), and topped by a foreshore-backshore succession (unit 10). Both the stepwise shallowing upward change and the gradual grain size increase indicate a single genetically related depositional cycle without abrupt facies shifts. The depositional cycle is bounded by a sharp erosive surface located between the fine-grained tidal mudflat deposits of FT3 (unit 10), and the erosive pebbly sandstone succession of FT2 (unit 11).

\section{Sil area; Meroy section (ME)}

The Meroy section is located in the northeastern limb of the Vega de los Viejos syncline along the east side of the road to El Puerto, $1 \mathrm{~km}$ north of the village of Meroy (Fig. 3).

Description: The boundary with the underlying PortiIla Formation is not exposed (Fig. 13). 


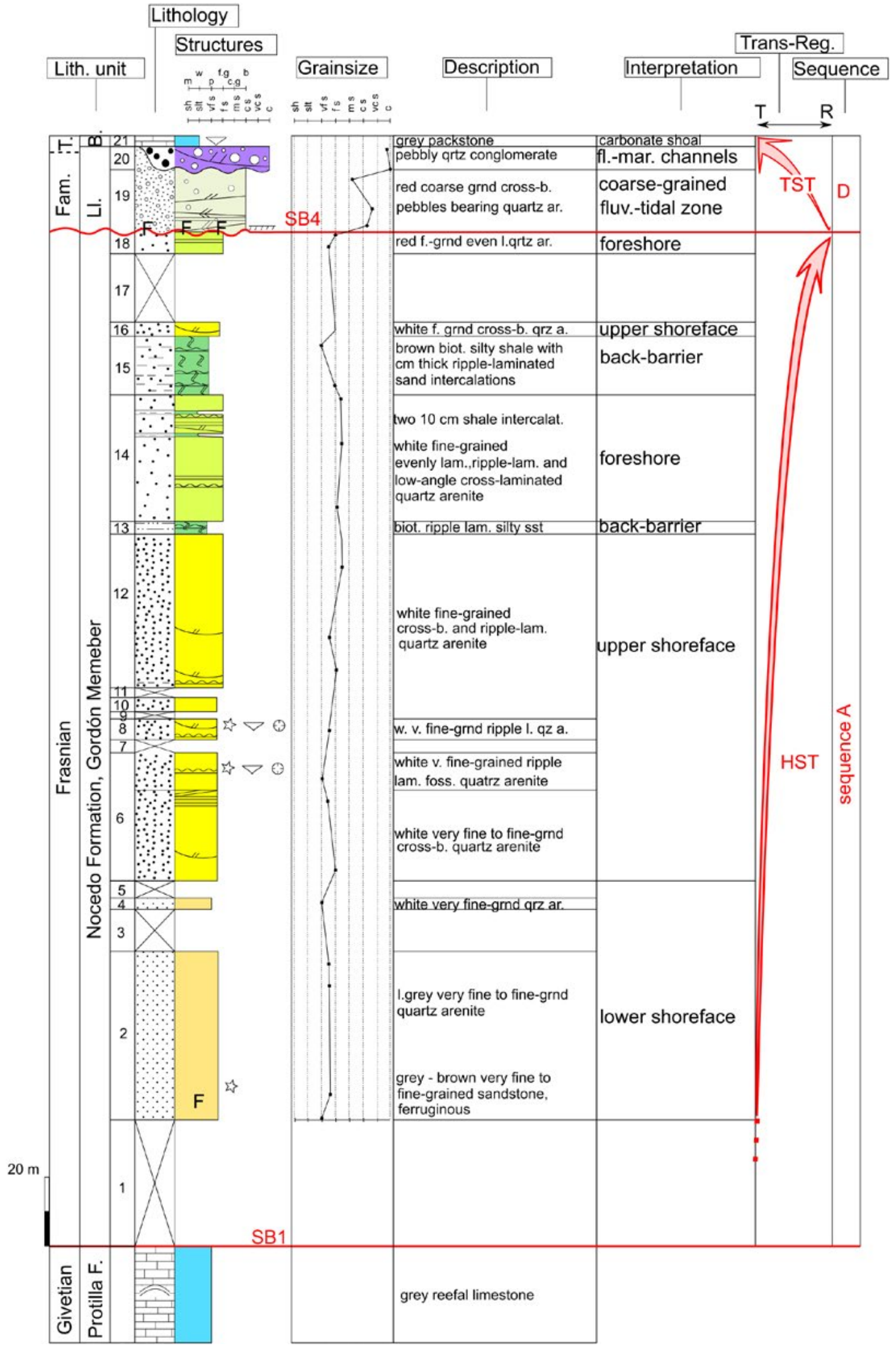

Figure 13. Log, grain size distribution, description, interpretation and sequence stratigraphy of the Meroy section. P. = Piñeres Formation, E. = Ermita Formation, LI. = Llombera Beds, B. = Baleas Formation; C. = Candamo Formation. For legend see Figure 6.

Figura 13. Columna, distribución granulométrica, descripción, interpretación y estratigrafía secuencial de la sección de La Cueta. P. = Formación Piñeres, E. = Formación Ermita, LI. = Capas de Llombera, B. = Formación Baleas, C.=Formación Candamo. (Leyenda en Fig. 6). 


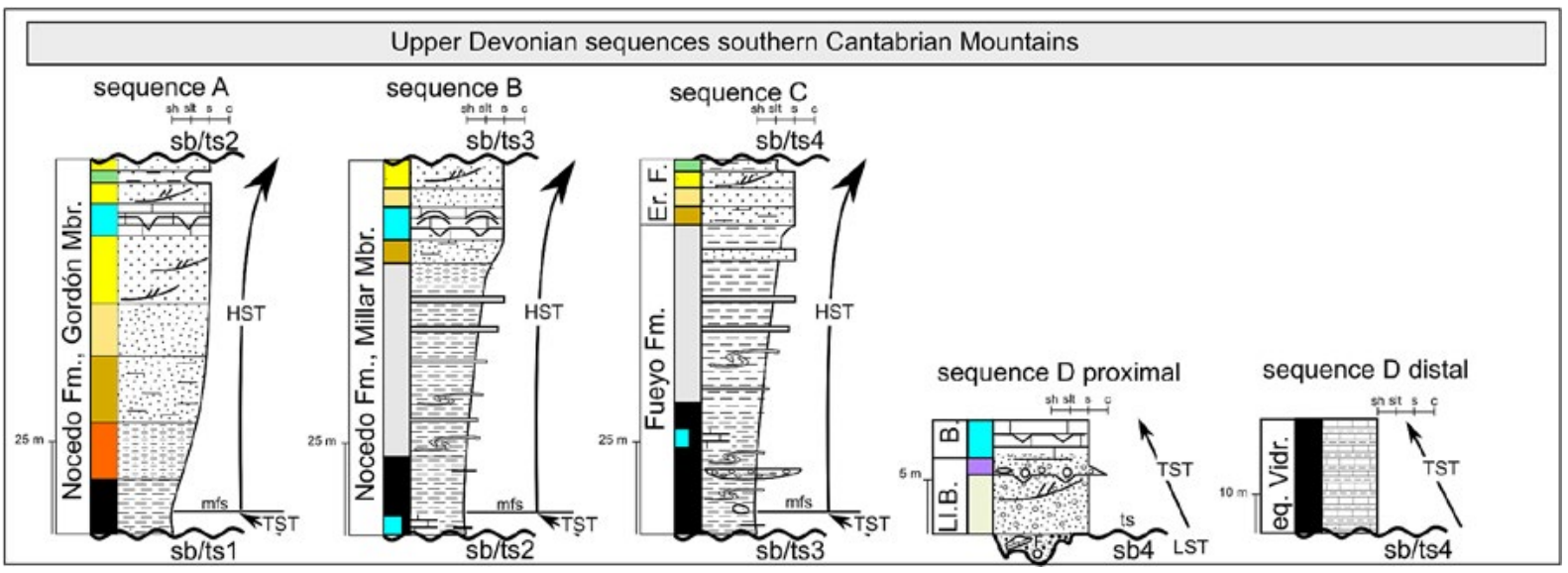

Figure 14. Sequence types of the southern Cantabrian Mountains with the sequence stratigraphical surfaces indicated. For legend see Figure 6.

Figura 14. Tipos de secuencias en el sur de la Cordillera Cantábrica con localización de las superficies estratigráficas secuenciales. (Leyenda en Fig. 6).

Van Loevezijn (1986) reported from an exposure 1.5 $\mathrm{km}$ south of section Meroy, near the village Vega de los Viejos on the north side of the road to La Cueta, a $2.5 \mathrm{~m}$ thick bioclastic grainstone bed (FT6c), $9.25 \mathrm{~m}$ above the top of the Portilla Formation (section VV in Van Loevezijn, 1986). The limestone bed contains the conodonts Polygnathus decorosus (Stauffer, 1938), and Icriodus aff. Subterminis (Youngquist, 1947) (sample VVC1). Both species occur commonly in the Nocedo Formation, Gordón Member (Bernesga and Esla areas), indicating an Early-Middle Frasnian age (Van Adrichem Boogaert, 1967; Raven, 1983).

Above, the section consists of $15 \mathrm{~m}$ grey-brown very fine to fine-grained ferruginous sandstone, grading upward to $33 \mathrm{~m}$ of light grey quartz arenites (FT7) (unit 2-5). Above a $97 \mathrm{~m}$ thick succession of white fine-grained cross-bedded quartz arenite occurs (FT5) (unit 6-12). In the middle part of the succession, a fossiliferous $20 \mathrm{~m}$ thick interval contains large amounts of imprints of coral, crinoids, and brachiopods (García-Alcalde, 1978: Apousiella gr. belliloci (Rioaux, 1908), Nervastrophia sp. A, and Cyrtospirifer sp.), indicating a Frasnian age. Above, a 78 $\mathrm{m}$ thick alternation of evenly laminated fine-grained quartz arenites (FT4), and ripple laminated silty sandstone and sandy silt occurs (FT3) (unit 13-18). The upper parts of units 13-18 approximately correlate with the lower part of section PF1 (Fernández et al., 2021), south of the Meroy section, near Piedrafita de Babia, with the brachiopod Atripida indet., indicating a pre-Famennian age. The succession is truncated by a sharp erosive boundary with ferruginous mineralisation. The overlying, $19 \mathrm{~m}$ thick, herringbone cross-bedded sandy conglomerate succession contains pebbles up to $2 \mathrm{~cm}$ (FT2) (unit 19). The section is topped by a $6 \mathrm{~m}$ thick conglomerate channel fill succession (FT1) exposed off the road $500 \mathrm{~m}$ uphill (unit 20). The conglomerate is finer upward and is overlain by the $3.5 \mathrm{~m}$ thick limestone succession of the Baleas Formation (FT6a) (unit 21).
Grain size distribution: The section displays a gradual coarsening upward from very fine-grained sand in the base of the section to fine-grained sand in the upper portion of the section, without major excursions. A grain size jump occurs $28 \mathrm{~m}$ below the top, from finegrained sandstone (FT4) to pebbly sandstone (FT2) between the units 18 and 19. A second excursion occurs $6 \mathrm{~m}$ below the top between the pebbly sandstone (FT2) and the overlying channel-fill conglomerates (FT1).

Interpretation: The facies stack indicates a gradual trend from lower shoreface deposits (units 2, 4), overlain by upper shoreface deposits (units $6,8,10$, 12), followed by a succession of mainly foreshore and back-barrier deposits (units 13-15, 18). Both the stepwise shallowing upward change without abrupt facies shifts, and the gradual grain size curve without major excursions, indicate one genetically related depositional cycle, similar to the La Cueta section. The cycle is truncated by a sharp boundary, with a grain size jump to microconglomerate, where the coarsegrained pebbly sandstone of unit 19 rest on the ferruginous, backbarrier deposits of unit 18. A downcutting channel-fill succession occurs at the top of the pebbly sandstone, overlain by the carbonate shoal deposits of the Baleas Formation.

\section{Sil area; Torrestío section $(T)$}

The $19 \mathrm{~m}$ thickTorrestío section is located $4 \mathrm{~km}$ west of the village of Torrestío in the nose of the Saliencia syncline (Fig. 3), where the Upper Devonian is distributed in broad discontinuous, laterally thinning successions.

Description: The boundary surface between the Portilla limestone and the overlying Upper Devonian sandstone is an undulating low-relief erosional karst surface (Van Loevezijn, 2020). The sandstone consists of ferruginous trough cross-bedded fine to middlegrained pebbly quartz arenites (FT2) (Fig. 15). Fossils do not occur in the succession. The upper ten metres of the section are not exposed. Above it, Namurian dolomites of the Barcaliente Formation occur. 


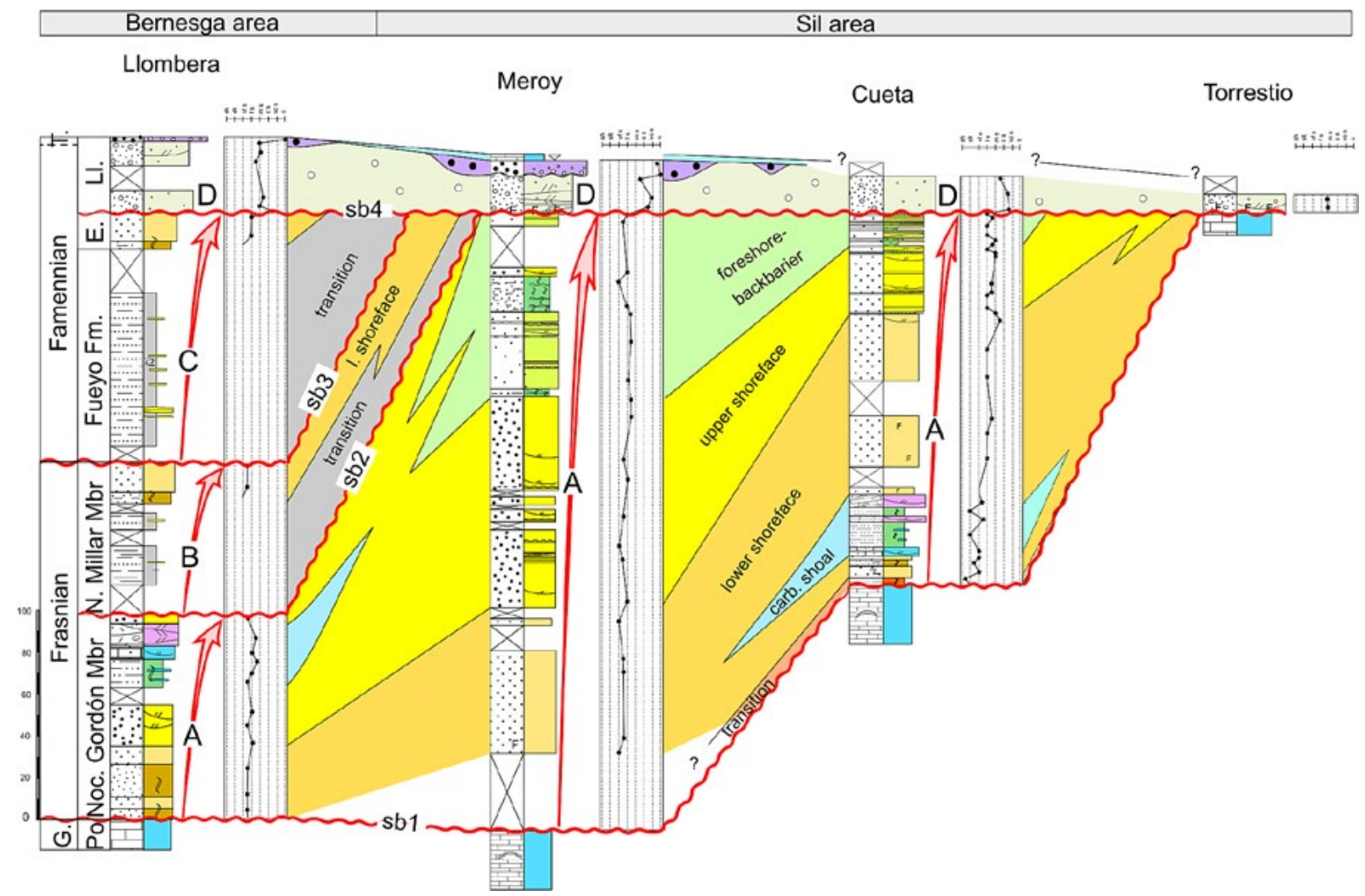

Figure 15. Upper Devonian correlation of sequences between the Sil area and the Bernesga area in León. Po. = Portilla Formation, Noc. = Nocedo Formation, E. = Ermita Formation, LI. = Llombera Beds. For legend see Figure 6.

Figura 15. Diagrama de correlación entre las secuencias del Devónico Superior de las áreas del Sil y Bernesga, en León. Po. = Formación Portilla, Noc. $=$ Formación Nocedo, E. = Formación Ermita, LI. = Capas de Llombera (Leyenda en Fig. 6).

Interpretation: An irregular palaeokarst surface separates the Portilla limestone from the overlying Upper Devonian sandstone. The discontinuous cross-bedded pebbly sandstone pockets (FT2) represent sand bars and channels of a shallow marine fluvial to tidal environment as described by Van den Berg et al. (2007).

\section{Asturias; Coastal Ranges; Playa de la Gargantera sec- tion (G)}

Sánchez de la Torre et al. (1976) and Raven (1983) described the Upper Devonian Piñeres Formation from the Playa de la Gargantera (Fig. 1c) at Antromero, SE of Luanco (Asturias). This is the thickest and most complete Upper Devonian outcrop of the Cabo Peñas area of the Asturian coastal range. The description of Sánchez de la Torre et al. (1976), completed with our own observations, was used for the facies interpretation and grain size distribution pattern of the Gargantera section (Fig. 17).

Description: Sánchez de la Torre et al. (1976) describe the basis of the Piñeres Formation in the Gargantera section as overlying a small outcrop of the the Candás Formation. Nowadays this part of the outcrop is covered in rubble from the unconformably overlying Cretaceous. Probably very little of the Piñeres Formation is missing, the section commences with a thick grey siltstone which grades into a thick package of massive yellow and red cross-bedded sandstone. Above it is a package of alter- nating shale, siltstone and mostly thin sandstone beds. Near the middle is a 3-metre-thick sandstone bank with an erosive base and abundant horizontal grazing traces, near the top the sequence there are more sandstone banks. The section ends with an angular unconformity, overlain by Cretaceous deposits.

Boundaries: The Gargantera section contains two sequence boundary surfaces: one surface is located above the Candás Formation, near the base of the Piñeres Formation (now not exposed). The second one is a sharp surface, formed through sub-aerial exposure and erosion (Sanchez de laTorre et al., 1976), and separates the cross-bedded sandstone from the overlying heterolithic shale-silt-sandstone succession.

Grain size distribution: The lower part of the section contains a coarsening upward from siltstone to middle to coarse grained sandstone which forms the bulk of these deposits. The overlying heterolithic succession becomes sandier near the top.

Interpretation: The coarsening upward succession indicates a gradual trend from transition zone (FT9) to lower shoreface deposits (FT8, 9), overlain by upper shoreface deposits (FT5), and topped by a foreshorebackshore succession $(F T 3,4)$. The stepwise shallowing upward and the gradual grain size-increase indicate one genetically related depositional cycle without abrupt facies shifts. A sharp erosional boundary surface with a 


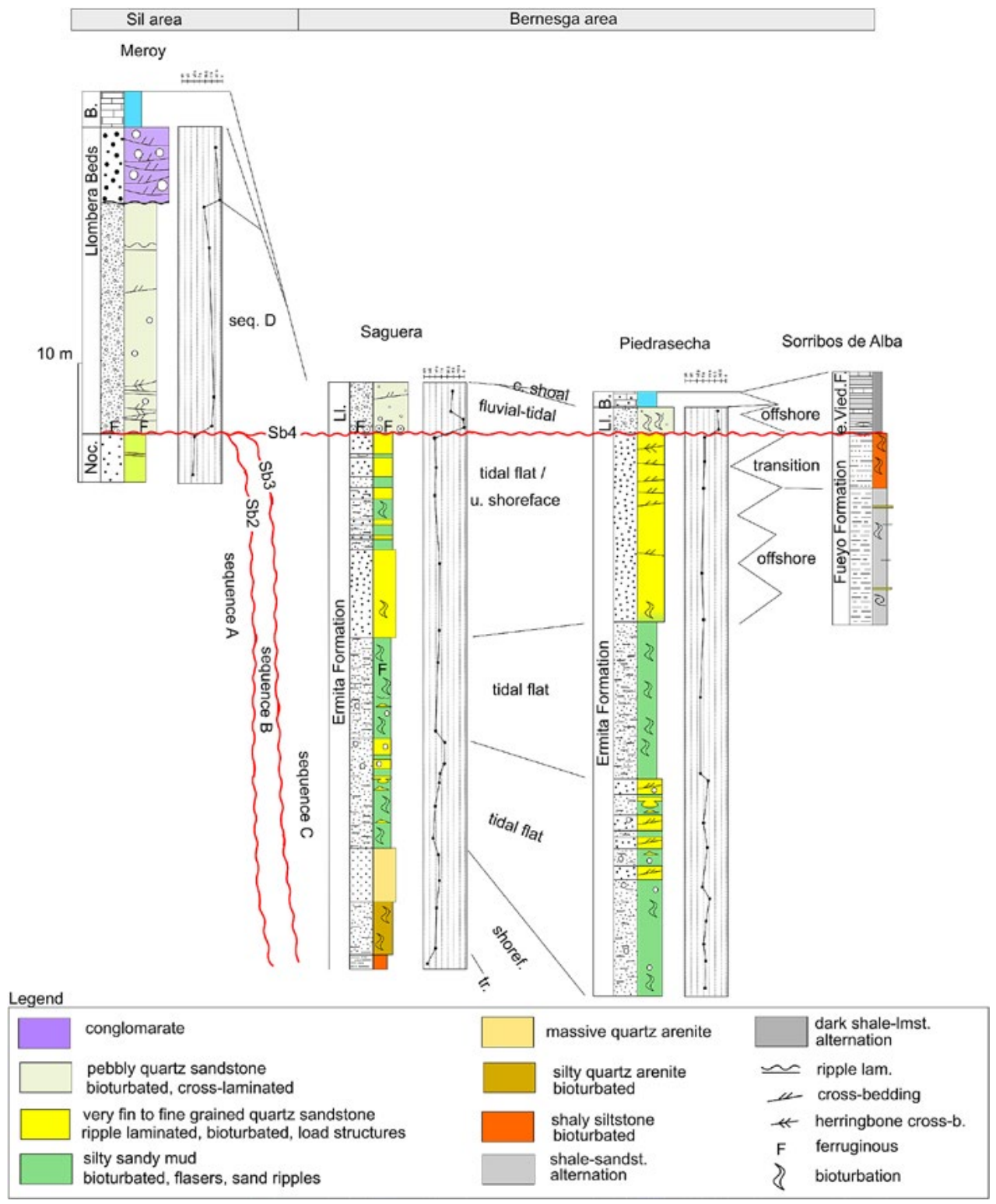

Figure 16. Detailed Famennian-Tournaisian correlation between the Sil and Bernesga areas in León. Noc. = Nocedo Formation, LI. = Llombera Beds, e. Vied. = equivalent of the Vidrieros Formation, C. = Candamo Formation; B. = Baleas Formation .

Figura 16. Diagrama detallado de correlación entre las áreas del Sil y Bernesga en León. Noc. = Formación Nocedo; LI. = Capas de Llombera; e. Vied. = equivalente de la Formación Vidrieros; C. = Formación Candamo; B. = Formación Baleas.

grain size jump to shale, separates the sequence from the upper part of the section, with a coarsening and shallowing upward shale-sandstone rhythmite succession (Sánchez de laTorre et al., 1976; Raven, 1983).

Asturias; Coastal Ranges; Playa de Boletos section (PB) García-López (1976, 1987) and García-López and Sanz López (2002b) described the Upper Devonian Piñeres Formation from Playa de Boletos, just SE of Luanco (initially considered part of the Candás Formation). This is the westernmost of the Upper Devonian outcrops of the Cabo Peñas area of the coastal range of Asturias, just $2 \mathrm{~km} \mathrm{~W}$ of the Playa de la Gargantera outcrop. At this locality the top of the Candás Forma- tion is well exposed (Figs. 18C, 18D). As García-López and Sanz-López (2002b) describe, the reefal limestone of the Candás Formation pass into a $5.5 \mathrm{~m}$ thick crinoidal packstone-grainstone succession, above which there is a sharp boundary with the overlying siltstone of the Piñeres Formation. In this outcrop the lower part of the Piñeres Formation comprises siltstone, sandstone, limestone and marls forming an overall coarsening upward sequence, and is thinner with more calcareous sediments than at La Gargantera. Only the basal part of the overlying unit with alternating siltstone and thin sandstone is exposed.

Boundaries: The Playa de Boletos section contains two sequence boundary surfaces: the erosive surface 


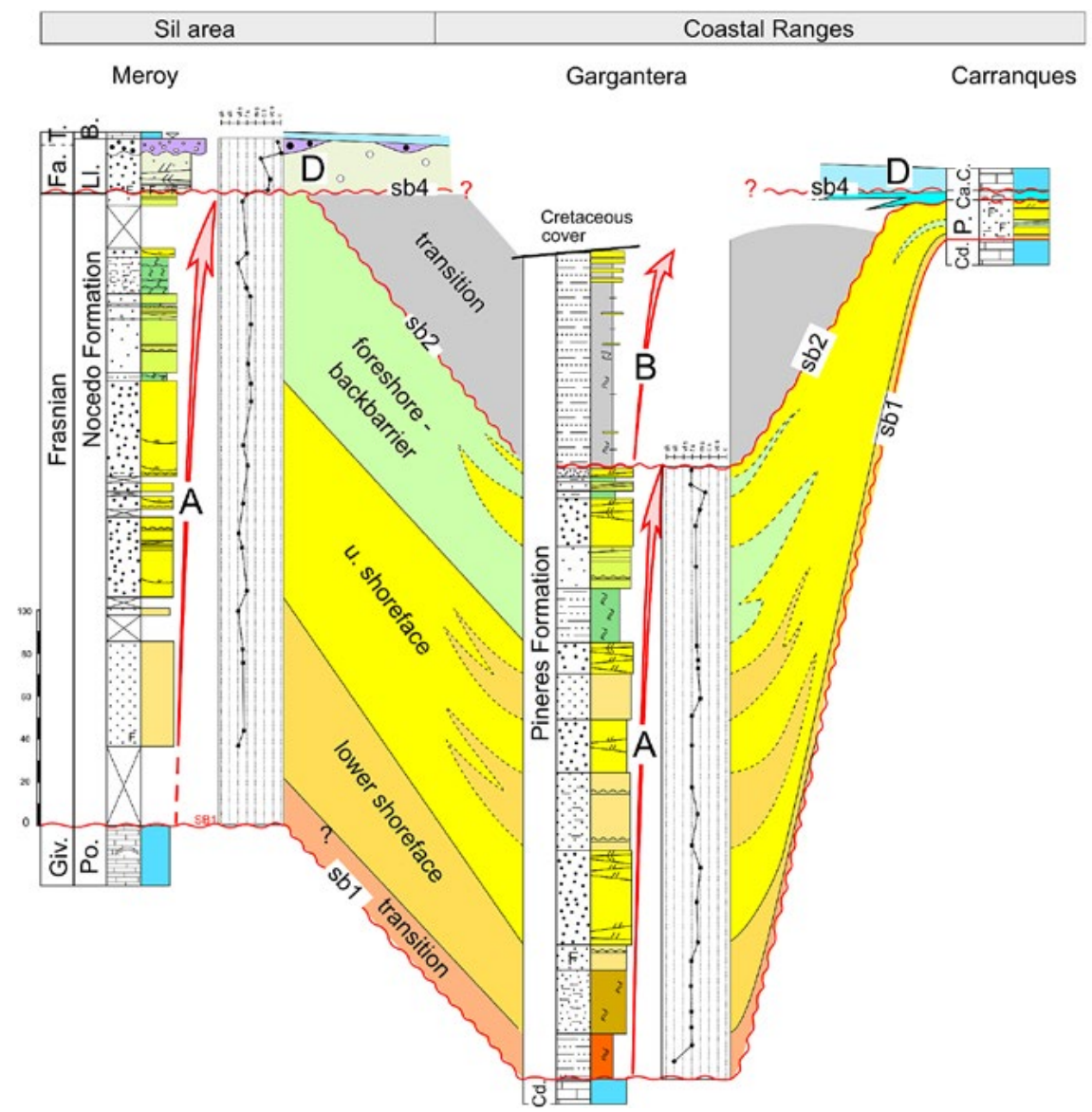

Figure 17. Correlation of the Upper Devonian of the Sil area and the Coastal Ranges in Asturias. The Gargantera Section is an interpretation after Sanchez de la Torre et al. (1976). Po. = Portilla Formation, Cd . = Candás Formation, Ca. = Carranques limestone, LI. = Llombera Beds, B. = Baleas Formation, C. = Candamo Formation. For legend see Figure 6.

Figura 17. Correlación del Devónico Superior entre las áreas del Sil y la costa de asturiana. La interpretación de serie de la playa de la Gargantera se basa en Sánchez de la Torre et al. (1976). Po. = Formación Portilla; Cd . = Formación Candás; Ca. = caliza de Carranques; LI. = Capas de Llombera; B. = Formación Baleas; C. = Formación Candamo. (Leyenda en Fig. 6).

separating the reef deposits of the Candás Formation from the carbonate-rich, but dominantly siliciclastic Piñeres Formation (Fig. 18D); García-López and Sanz-López, 2002b). The second surface is also sharp, formed through sub-aerial exposure and erosion, and separates the massive cross-bedded sandstone from the overlying siltstone (Figs 18E, 18F).

Interpretation: The coarsening upward succession indicates a gradual shallowing upward trend. A sharp erosional boundary surface with a grain size jump to siltstone separates the sequence from the overlying unit.

\section{Asturias; Coastal Ranges; Carranques section (CARR)}

In the eastern sections of the Cabo Peñas area, the Upper Devonian thins to a 22-26 m (Perlora syncline, Playa de Carranques (Fig. 1c); Sánchez de la Torre (1977), Raven (1983), García-López and Sanz-López 2002b) Fernández-Martínez et al., (2008).

Description: The Piñeres Formation at Carranques has a thickness of $22 \mathrm{~m}$ and can be sub-divided into two parts (Sánchez de la Torre (1977): the $19 \mathrm{~m}$ thick lower part mainly consists of ferruginous very fine to fine grained sandstone (FT5). Bioclastic and silty intercalations occur in the base of the formation, close to the underlying Candás limestone. Above irregular bedded ferruginous, burrowed, sandstone with irregular discontinuity surfaces and low-angle cross-lamination can be observed (FT4 and FT5). Cross-bedding organised in herringbone structures occur in the uppermost part of the unit (FT5) (Fig. 18B). An irregular erosion surface separates the ferruginous sandstone from the second part of the section, a $3.5 \mathrm{~m}$ thick limestone unit of Frasnian age (García-López and Sanz-López, 2002b), in this study informally named the Carranques limestone. It consists of cross-bedded grainstone in the base (FT6a), followed by biostromal developments at the top. The succession is overlain by a 10-12 $\mathrm{m}$ thick crinoidal limestone succession of the Candamo Formation (Fernández et al., 1995; García-López and Sanz-López, 2002b).

Boundaries: The Carranques section contains three boundary surfaces: one surface is located between the limestone (Candás Formation) and the mainly siliciclastic succession of the overlying Piñeres Forma- 
tion (Fig. 18A), although few bioclastic intercalations close to the base indicate a transitional development to the siliciclastic environment. The second boundary is a sharp erosional surface between the ferruginous sandstone unit and the overlying Carranques limestone unit in the top of the Piñeres Formation (Sánchez de la Torre, 1977). The third boundary is also a sharp erosional surface, located between the Carranques limestone unit and the overlying crinoidal limestone succession of the Candamo Formation (Van Adrichem Boogaert, 1967; Fernández-Martínez et al., 2008).

Interpretation: The cross-lamination organised in low angle and herringbone structures indicates an environment of bars and troughs in a turbulent sha- llow marine zone (Nichols, 2009) (FT5), where locally erosive tidal currents carved into the sediment, and where silty sediment was deposited in the protected sheltered zones behind the sand bars (FT4) (Reinson, 1979; Nichols, 2009). The overlying cross-bedded sandy grainstone of the Carranques limestone unit represent carbonate shoals, which developed in the turbulent coastal zone. The bioclastic debris stabilised the sediment, and small biostromal developments could bloom characterised by colonies of Disphyllum. The crinoidal limestone succession of the overlying Candamo Formation is formed by deposition on bars and coastal shoal areas (Raven, 1983; García-López and Sanz-López, 2002b).

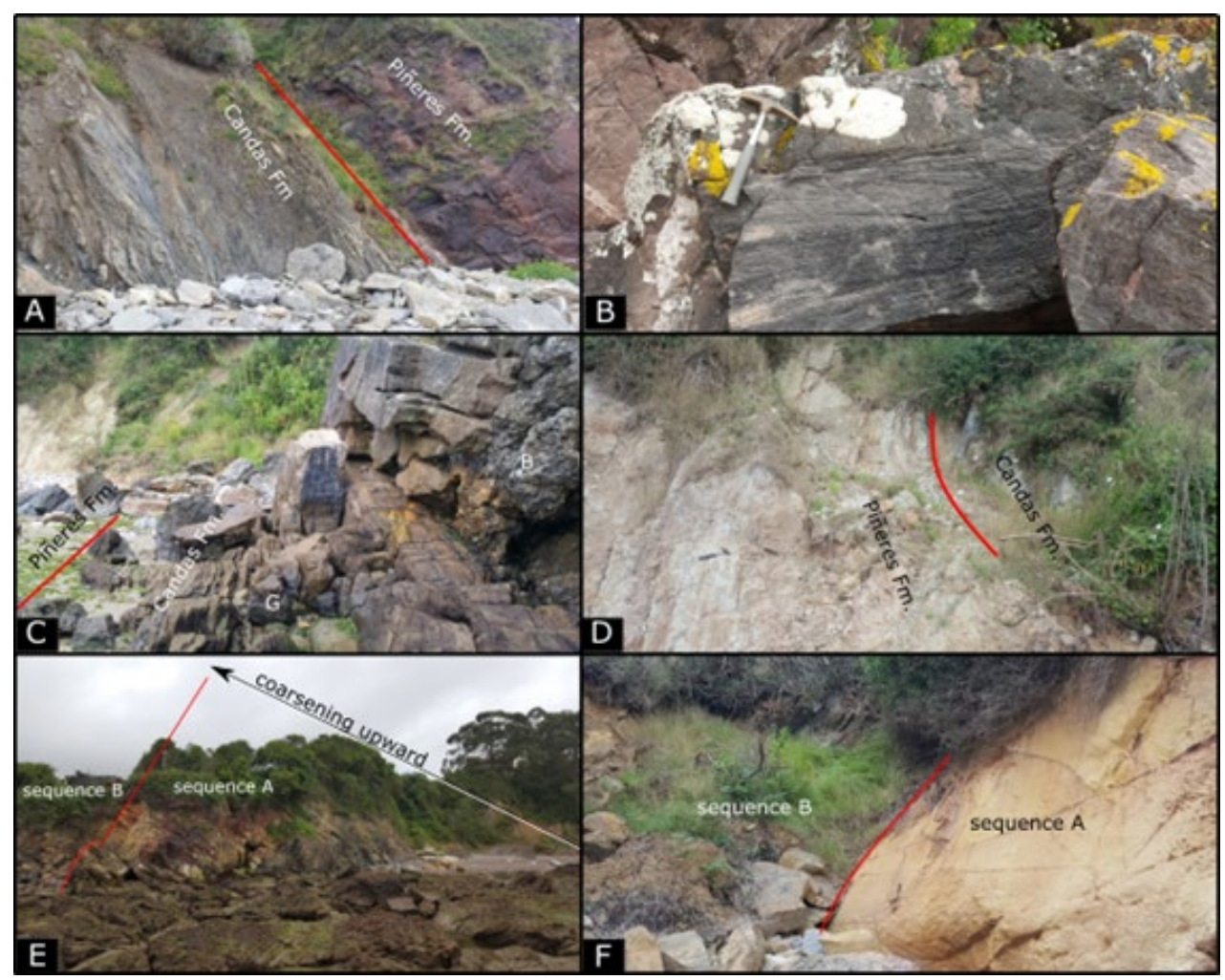

Figure 18. A) Boundary between the Candás and Piñeres formations at Playa de Carranques, Perlora, Asturias. On the left the grey Candás Formation with biostrome passing into shale, on the right the overlying Piñeres Formation with thick, red cross-bedded sandstones. The difference in depositional angle between both formations and the large difference in thickness indicates an erosive contact. B) Crossbedded sandstones of the Piñeres formations at Playa de Carranques, Perlora, Asturias. C) Boundary between the Candás and Piñeres formations at Playa de Boletos, Luanco, Asturias. The photograph shows the reefal limestones of the Candás Formation (B) overlain by a crinoidal packstone-grainstone succession (top just left of the hammer) (G) - as exposed on the beach. D) The boundary between the Candás and Piñeres Formations a few metres uphill from Figure 18C. Limestone of the Candás Formation is visible on the right, with eroded top and overlain by siltstones of the Piñeres Formation. E) The boundary between sequences $A$ and B of the Piñeres Formation at Playa de Boletos, Luanco, Asturias, with the massive cross-bedded sandstones in the top of sequence A overlain by the siltstones in the base of sequence $B$. F) irregular top surface of sequence $A$ of Figure 18E, formed through sub-aerial exposure and erosion.

Figura 18. A) Límite entre las formaciones Candás y Piñeres en la playa de Carranques (Perlora). A la izquierda, en tonos grises, la Formación Candás, con un biostromo pasando a lutitas; superpuestas; a la derecha, las potentes areniscas rojas con estratificación cruzada de la Formación Piñeres. La diferencia en el ángulo deposicional y espesor entre ambas unidades indica un contacto erosivo entre ellas. B) Areniscas con estratificación cruzada en la Formación Piñeres en la playa de Carranques. C) Límite entre las formaciones Candás y Piñeres en la playa de Boletos (Luanco). La fotografía muestra dicho afloramiento las calizas arrecifales de la Formación Candás (B) cubiertas por calizas packstonegrainstone crinoidales (justo izquierda del martillo). D) Contacto entre las formaciones Candás y Piñeres pocos metros más arriba de la Fig. 18C. Las Calizas de Candás son visibles a la derecha con techo erosivo bajo por lutitas de la Formación Piñeres. E) Límite entre las secuencias $A$ y $B$ de la Formación Piñeres en la playa de Boletos con las areniscas masivas con estratificación cruzada de la secuencia A cubiertas por lutitas de la base de la secuencia B. F) Superficie erosiva irregular del techo de la secuencia A de la Fig. 18E, formada por exposición subaérea y erosión. 


\section{Correlations}

The recently proposed Upper Devonian sequence stratigraphical scheme of Van Loevezijn and Van Loevezijn Peña (2017) provides a useful correlation tool for the Sil area (Fig. 14). The model contains a total of four sequence boundaries (sb1 to 4), representing non-adjacent facies shifts to deeper water, and/or regional erosional events. They divide the Upper Devonian into four unconformly-bounded sequences A, B, C, and D. Within the sequences, the three systems tracts model with "lowstand systems tracts" (LST), "transgressive systems tracts" (TST), and "highstand systems tracts" (HST) is used (Catuneanu, 2017). LST sediments are often absent in the shallow-marine Asturo-Leonese Basin, therefore the sequence boundary (sb), and transgressive surface (ts) merge into a single sb/ts combined surface. The sequences are characterised by abrupt deepening events, separated by the maximum flooding surfaces ( $\mathrm{mfs}$ ) from the overlying prolonged gradual shallowing upward systems. However, in the Cantabrian Mountains the Upper Devonian sequence boundaries are not sharp erosive surfaces everywhere. Towards the core of the Cantabrian Zone, in the proximal parts of the basin the depositional sequences are often bounded by downcutting erosional surfaces, but in the outer distal part of the basin, the sequence boundaries are correlative conformities, depositional surfaces that correlate to updip erosional surfaces (Van Loevezijn, 2020). Moreover, Frasnian climate is characterised by extreme greenhouse conditions (Vleeshouwer et al., 2014), and as a consequence, sea-level fluctuations had a low amplitude (Csato and Cataneanu, 2012), resulting in gradual shifting facies belts and depositional transitions, instead of pronounced erosive disconformity bounding surfaces (Van Loevezijn and Raven, 2017). For a more detailed discussion of the Cantabrian Upper Devonian sequence stratigraphy the reader is referred to Van Loevezijn and Van Loevezijn Peña (2017), Van Loevezijn and Raven (2017) and Van Loevezijn (2020).

\section{Sil-León correlation}

The Meroy and La Cueta sections have a similar stratigraphical architecture. A total of two boundary surfaces with a regional extension can be identified (Fig. 15); the first is located between the reef deposits of the Portilla Formation and the overlying siliciclastics of the Nocedo Formation and can be correlated with sb1 in the Bernesga area. The second is located between the transition zone-foreshore shallowing upward succession and the overlying pebbly sandstone and conglomerates. The two bounding surfaces divide the Upper Devonian succession into depositional cycles. The first contains the major part of the succession. The facies stack is organised in a $4 \mathrm{~m}$ thin succession of silt and shale representing the transgressive TST, and a prolonged shallowing upward HST succession from transition silty deposits to foreshore sands, with a carbonate shoal intercalation in the lower part of the facies stack. A brachiopod fauna in the middle of the sequence indicates a Frasnian age, and the sequence can therefore be correlated with Frasnian sequences $A$ or $B$ in the Bernesga area. Internally the facies stack is very similar to sequence $A$, with a gradual shallowing upward change from transition silts to shoreface sandstone, and without the storm-bedded shale-sandstone rhythmites (which are characteristic for sequences $B$ and $C$ ).

The upper part of sequence $A$ in the Bernesga area contains conodont faunas from the Upper valsiovalis, Lower hassi, and Upper hassi zones (García-López and Sanz-López, 2002a; Van Loevezijn and Van Loevezijn Peña, 2017), and is of early-middle Frasnian age. This is in accordance with the suggested Frasnian age as indicated by the brachiopod and conodont faunas in the Meroy section (García-Alcalde, 1978; Van Loevezijn, 1986). The architecture of the facies stack of the Lumajo section above sb1, with a gradual shift from shale to silt, followed by sandstone, without a tempestite succession, is also very similar to sequence $A$ in the southern part of the Bernesga area. The limestone unit in section La Cueta has a similar facies stack as the Molino Limestone (Van Loevezijn and Raven, 2017), with fine grained silty wackestone and sandy grainstone, overlain by coarse-grained bioclastic grainstone. It is intercalated within the lower half of the facies stack of sequence $A$; in the Bernesga area the Molino limestone occurs higher in the sequence. South of Lumajo the Puente de las Palomas section occurs. Van den Bosch (1969) and Van Loevezijn (1986) correlated the shale sandstone interbedded succession in the lower part of the section with the Fueyo Formation. Above it the cross-bedded quartz arenites of the Ermita Formation occur (Fig. 9). Together they constitute part of sequence $C$ of the Upper Devonian sequence stratigraphic model (Van Loevezijn and Van Loevezijn Peña, 2017). The upper boundary of sequence $\mathrm{C}(\mathrm{sb} 4)$ is located at the base of the pebbly sandstone breccia in the top of the section. The overlying sandy crinoidal grainstone unit in the top of the section is part of the Baleas Formation.

The second boundary surface in the Sil area, exposed in the sections Puente de las Palomas, Meroy, and La Cueta, is a flat, undulating, erosive bounding surface, and separates sequences $A$ and $C$ from the overlying 24-28 m thick (herringbone) cross-bedded pebbly sandstone, conglomerate and limestone. In the Bernesga area cross-bedded pebbly sandstone occurs in the Llombera Beds above sb4. Indeed, the thickness and facies of the Sil succession are very similar to the characteristics of the pebbly sandstone succession of the Llombera Beds in the Bernesga area. Therefore, here we propose to correlate the second boundary in the Sil area with sb4, the Upper Devonian Unconformity, and the overlying coarse deposits with the transgressive Llombera Beds. Minor erosion surfaces are associated with the sb4 erosional event, 
and the overlying coarse-grained succession contains several hiatuses (Van Loevezijn and Raven, 2017). These beds represent a very condensed succession of a sediment starved environment, where erosional discontinuity surfaces and hardground were generated (García-López and Sanz-López, 2002a; Van Loevezijn, 2020). Fernández et al. (2021) indicate several minor unconformity surfaces immediately above the Upper Devonian Unconformity sb4 in the Vega de los Viejos syncline. The down cutting discontinuous channel-fill conglomerates in the upper part of the Llombera Beds of the Sil area probably represent one of the many local erosion events above the Unconformity. The conglomerate occurs in the Meroy section, and is locally present in the southern Cantabrian Mountains. It is deposited as an upward fining channel-fill and has a gradational contact with the overlying transgressive sandy crinoidal packstone - grainstone succession of the Baleas Formation, e.g., Bernesga area, Luna section (Van Loevezijn, 2020); Ventanilla area, San Martín de los Herreros section (Raven, 1983). The conglomerates are locally present. Probably in most localities coarse sediment channels eroded the surface without deposition, leaving only an erosional surface in the sedimentological record. Towards the core of the Cantabrian Zone, in the northeastern part of the Sil area, the erosional event of sb4 increases; in section Torrestío the Upper Devonian Unconformity carves a relief of up to $20 \mathrm{~m}$ into the limestone of the Givetian Portilla Formation, and the karst topography is filled by Upper Devonian ferruginous pebbly sandstone (Fig. 15). In Figure 16 the Llombera Beds of the Meroy section are correlated with successions in the southern Bernesga area, where the Llombera Beds rest on the upper part of the Ermita Formation of sequence C. The underlying deposits consist of poorly sorted alternation of sand and mud deposits containing scattered granules of up to $3 \mathrm{~mm}$, with mud flasers, lenticular thin sand layers, rippled sand, and plant remains. Some of the sand layers sank into the mud layers, producing ball-and-pillow load structures. The beds are strongly bioturbated. Reineck and Singh (1975) described similar deposits from the tidal flat area bordering the German North Sea. Sb4, the Upper Devonian Unconformity, separates these deposits from the overlying thin succession of pebbly sandstone, conglomerates and sandy bioclastic limestone of the Llombera Beds of sequence D. In the southernmost part of the Bernesga area the Llombera Beds are replaced by a thin bedded dark shaly limestone alternation of the "equivalent of the Vidrieros Formation" (Van Loevezijn and Van Loevezijn Peña, 2017).

\section{Sil-Asturias correlation}

The Piñeres Formation of the Playa de la Gargantera and Playa de Boletos sections contain two sequences (Fig. 17). The tops of the sections are covered by Cretaceous deposits therefore the Upper Devonian Piñeres development is not completely exposed. The lower sequence is characterised by a gradual shallowing upward facies developing, from silty transition deposits in the base to foreshore-backshore sand at the top, without a tempestite intercalation and is interpreted as an HST succession.

The HST facies stacking pattern and its stratigraphic position above the Givetian reef deposits are similar to sequence $\mathrm{A}$ in the Sil and Bernesga areas, and correlates well. The overlying shale-sandstone alternation in the Asturian coast section must be part of Frasnian sequence $B$ or part of Famennian sequence $C$; both sequences contain a thick upward shallowing tempestite succession (Van Loevezijn, 2020). In this study it is tentatively correlated with sequence $B$, because of its stratigraphic position immediately above sequence $A$, although the gravity flow signature would also correlate well with the Fueyo Formation. In the eastern part of the Cabo Peñas area of the coastal range, the Piñeres Formation consists of a lower sandstone unit (approximately $20 \mathrm{~m}$ thick) and an upper limestone unit (approximately 2-4 m thick), separated by an irregular erosion surface (Sánchez de la Torre, 1977). Lithology and stratigraphic position of the sandstone unit on top of the Givetian reef deposits are very similar to the sandy developed $A$ sequence elsewhere in the Asturo-Leonese Basin. The overlying limestone unit of the Carranques section has been considered to be late Frasnian or slightly older, without exact specification (García-López and Sanz-López, 2002b), and therefore falls within sequence $B$ of the Upper Devonian sequential scheme. A sharp erosional surface separates the Carranques limestone unit from the overlying 10-12 m thick crinoidal limestone succession of the Candamo Formation. The erosion surface can be correlated with the Upper Devonian Unconformity (sb4), and the overlying limestone is attributed to sequence $D$.

\section{Correlation chart}

Figure 19 shows the Upper Devonian correlation scheme of the Asturo-Leonese basin. The Sil area connects the southern Leonese succession with the Upper Devonian of the Asturian Coastal Ranges in the north. In León the sequence boundaries 1 to 4 separate sequences $A$ to $D$. In the southwestern limb of the Vega de los Viejos syncline of the Sil area only sequence $A$, parts of sequence $C$, and sequence $D$ are exposed. Sequence B may be present, but the unconformable Stephanian cover prevents an unambiguous interpretation. In the northeastern limb of the Vega de los Viejos syncline and in the La Cueta syncline the Upper Devonian Unconformity (sb4) cuts down to sequence $A$. Above it the Llombera Beds of sequence D occur. Further to the northeast, in the nose of the Saliencia syncline, the erosion surface of the Upper Devonian Unconformity erodes the limestone of the Portilla Formation. Above the unconformity a thin, irregular and patchy distributed veneer of sediment of the Llombera Beds of sequence D occurs. In the 


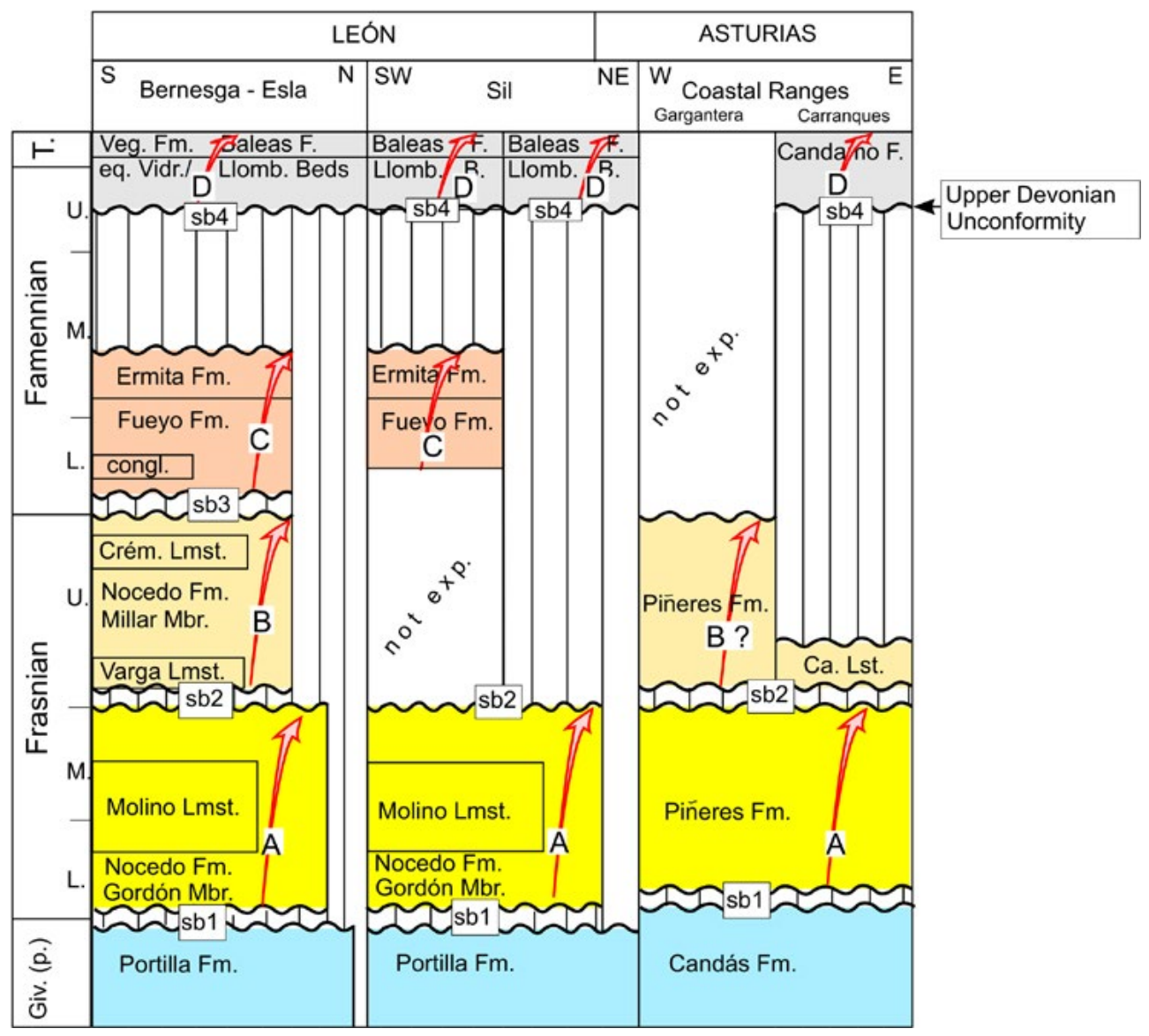

Figure 19. Correlation chart of the Upper Devonian rocks of the Asturo-Leonese facies area in the Cantabrian Zone, including lithostratigraphic nomenclature of the southern Bernesga and Esla areas, the Sil area, and the northern Coastal Ranges. The wavy lines represent the sequence boundaries, and sequences are indicated by red arrows. Ca. = Carranques limestone; Crém. = Crémenes Limestone.

Figura 19. Esquema de correlación de los depósitos del Devónico Superior de facies Astur-Leonesa en la Zona Cantábrica, incluyendo la nomenclatura litoestratigráfica del las áreas del Bernesga, Sil y Cabo Peñas. Las líneas ondulantes representan límites de secuencias. Las flechas de color rojo señalan la extension de cada una de secuencias. Ca. = Caliza de Carranques; Crém. = Caliza de Crémenes.

Gargantera section of the coastal range sequences A and probably sequence $B$ occur. There is a possibility that the overlying sequence $C$ is also present, but that stratigraphic part is covered by Cretaceous deposits. The erosion events increase towards the core of the Cantabrian Zone, and in the eastern sections of the Cabo Peñas area, the Piñeres Formation consists of a thin truncated sandstone succession, about $20 \mathrm{~m}$ thick, attributed to sequence $A$, and an overlying $3 \mathrm{~m}$ thick reef development, the Carranques limestone, attributed to sequence $\mathrm{B}$. Above sb4 the 10 to $12 \mathrm{~m}$ thick limestone succession of the Candamo Formation of sequence $D$ follows.

\section{Sedimentation models of the sequences}

Sequence $A$ : in Figure 20 an attempt is made to incorporate the facies types of sequence $A$ into the depositional model of the Sil area. The shelf transect displays a low depositional slope profile with gradual transitions, indicated by the gradual facies successions. Updip towards the northeast extensive foreshore (FT4) and tidal flat areas (FT3) existed. In the foreshore area, the swash-backwash mechanism, responsible for the distinct sub-parallel to low-angle planar laminations, marks the beach face. The extensive tidal sand flat area is characterised by fine grained ripple laminated sand and ferruginous hardground, the mud flats by flaser bedding and lenticular layered mud and sand. In more distal depositional settings, sands bars and troughs of the shoreface environment (FT5) gradually occur, grading downdip into the bioturbated sand of the deeper lower shoreface (FT8), where locally carbonate shoals developed (FT6). In the outer part of the basin a transition environment below fair-weather wave base existed, where silty sediment was deposited with a very intense biogenic reworking (FT8, 9). The seaward located offshore area was beyond the reach of the coastal silt and sand supply; there the finest sediment settled from suspension (FT11).

Sequence B: Sequence B deposits are not exposed in the Sil area. In the southwestern part of the Vega de los Viejos syncline the lower part of the Upper Devonian is covered by Stephanian deposits, and northward near 
Lumajo the Upper Devonian the succession is truncated by a fault plane. Probably because of the relative landward palaeogeographic position close to the core of the Cantabrian Zone, the distal clastic wedges of the sequences $B$ and $C$ do not occur in the stratigraphical record of the Meroy, La Cueta and Torrestío sections, and these wedges are represented by a hiatus.

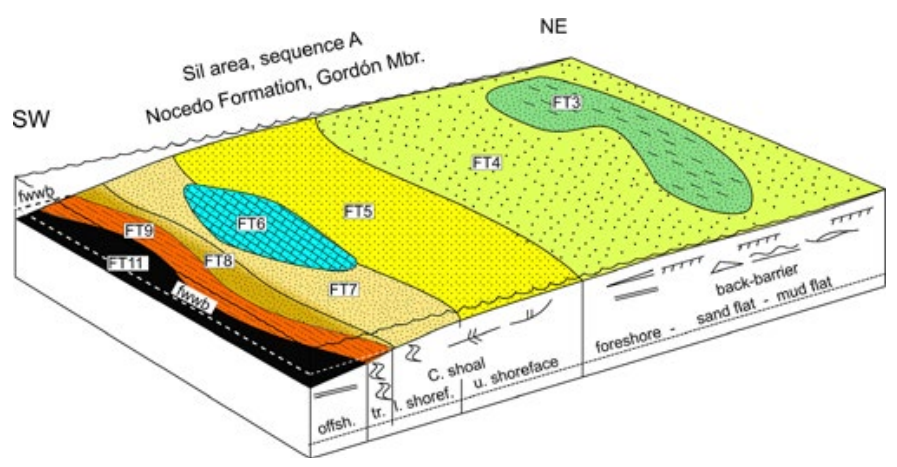

Figure 20. Depositional model of sequence $A$ in the Sil area. For legend see Figure 6.

Figura 20. Modelo sedimentario de la secuencia A en el área del Sil. (Leyenda en Fig. 6).

Sequence $C$ : The facies types of sequence $C$ in the Puente de las Palomas section are the building bloc$\mathrm{ks}$ of the depositional model in Figure 21. Towards the northeast, a sand flat area is assumed (FT4), where fluviomarine channels transported their coarse sand and conglomerate load to the basin (FT1). Seaward a coastal zone existed where the coarse sediment entered the basin, and was redistributed by tidal currents $(\mathrm{FT} 2,5)$, with a distal fining to the bioturbated fine sand area of the lower shoreface zone (FT7, 8). In the outer part of the basin, below fair-weather wave base, the transition zone existed where storm beds were deposited, with background sediments represented by bioturbated silty shale (FT10).

Sequence $D$ : Figure 22 shows the depositional model of sequence $D$. The succession represents a very

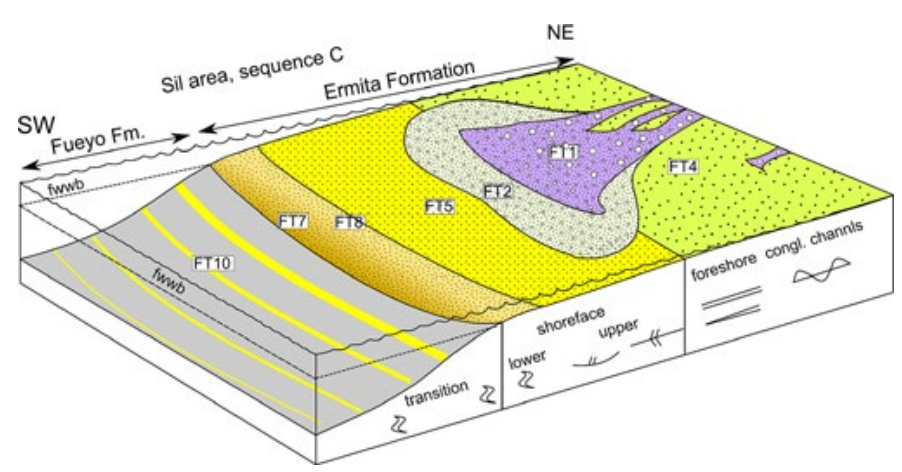

Figure 21. Depositional model of sequence $C$ in the Sil area. For legend see Fig. 6.

Figura 21. Modelo sedimentario de la secuencia C en el área del Sil. (Leyenda en Fig. 6). condensed sediment starved environment with hardground, erosion and mineralisation surfaces (García-López and Sanz-López, 2002a; Van Loevezijn, 2020). The shelf transect displays a low depositional slope profile, with a proximal fluviomarine zone of channels (FT1) and coarse sandy carbonate shallows (FT6), and a distal fluvial-tidally influenced coastal area, characterised by cross-bedded pebbly sandstone (FT2).

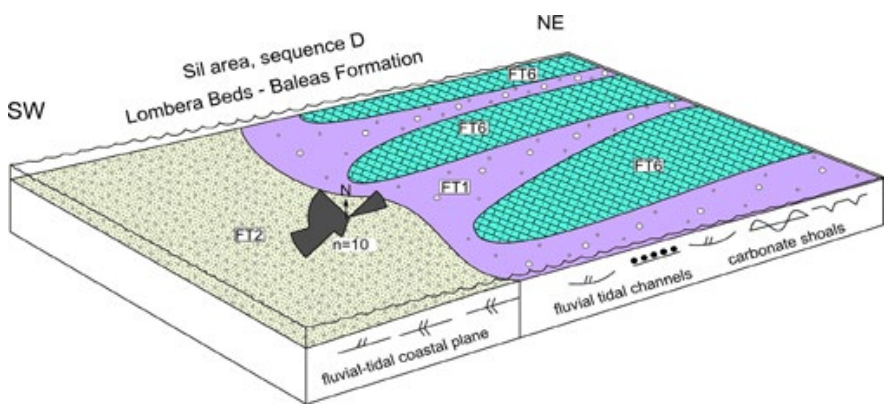

Figure 22. Depositional model of sequence $D$ in the Sil area. Rose diagram derived from cross- laminations of FT2 is bimodal and shows a predominant SW orientation with a minor NE orientation, indicating periodically reversed tidal currents. For legend see Figure 6.

Figura 22. Modelo sedimentario de la secuencia $D$ del área del Sil. El diagrama de paleocorrientes obtenido de laminaciones cruzadas de FT2 es bimodal y muestra una orientación NE dominante, indicando inversion periódica de las corrientes de marea. (Leyenda en Fig. 6).

\section{Depositional history Sil area}

Frasnian: The Frasnian is characterised by subtle regional tectonic activity, and extreme greenhouse conditions (Van Loevezijn and Raven, 2017; Van Loevezijn, 2020). Sea-level fluctuations were low-amplitude, with gradual shifting facies belts and depositional transitions. Sediments were laid down on a gradual depositional profile with the bathymetrical centre in the External Zone in the southwest, where a succession of laminated shale and bioturbated silt of the offshore-transitional zone was deposited (Fig. 23). The depositional area extended outside the External Zone to the northeast, where a succession of cross-bedded and laminated sand was deposited in a shoreface-foreshore environment, with a mudflat zone in the northeast close to the central part of the Cantabrian Zone. The succession displays a gradual thickness distribution pattern between $170-250 \mathrm{~m}$ in the core of the Sil area without major thickness changes. Northeastward, in the proximal part of the Asturo-Leonese Basin, it thins rapidly, and Frasnian deposits are absent in the nose of the Saliencia syncline. The hinge line separates the depositional area with the Frasnian sandstone succession in the centre of the Sil area, from the north-eastern zone with a near-complete absence of 


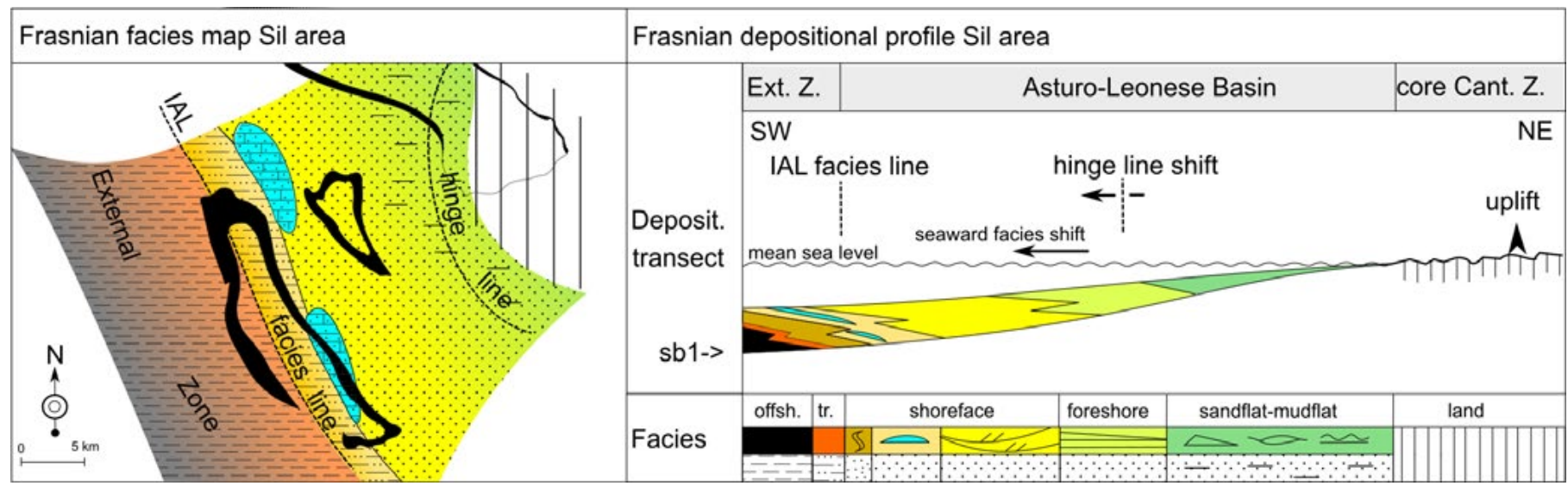

Figure 23. Frasnian palaeogeography of the Sil area. The black silhouettes correspond to the outcrops of the Nocedo, Fueyo and Ermita formations. For legend see Figure 6.

Figura 23. Paleogeografía del área del Sil durante el Frasniense. En línea negra se resaltan los afloramientos del Devónico Superior. (Leyenda en Fig. 6).

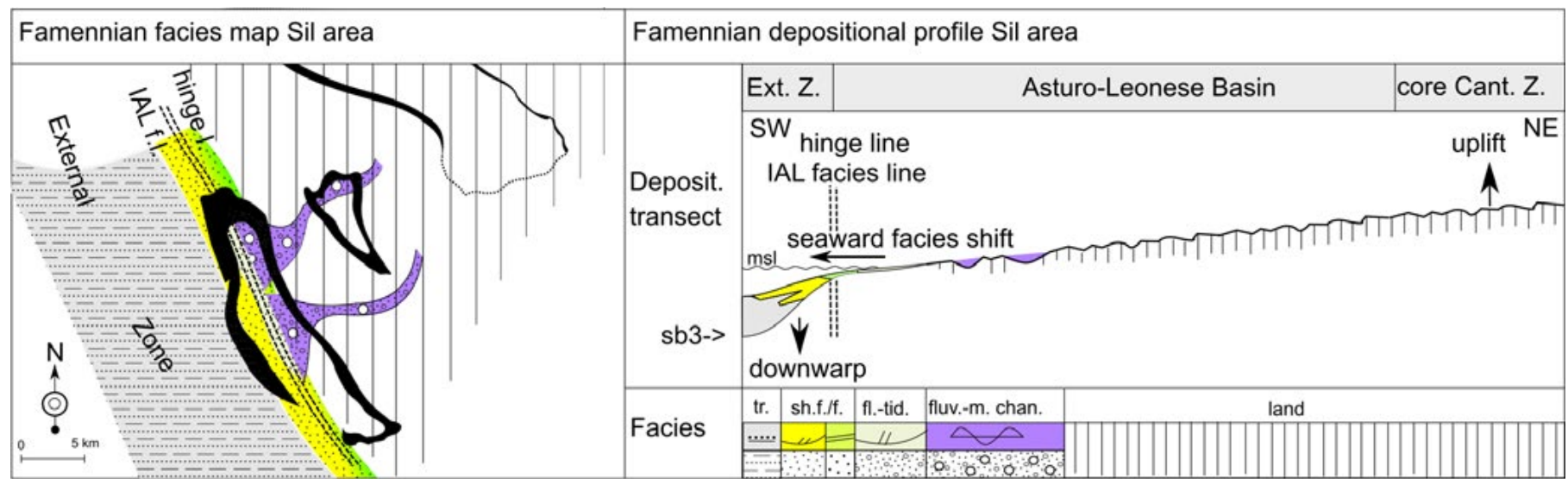

Figure 24. Famennian palaeogeography of the Sil area. The black silhouettes correspond to the outcrops of the Nocedo, Fueyo and Ermita formations. For legend see Fig. 6.

Figura 24. Paleogeografía del área del Sil durante el Famenniense. En línea negra se resaltan los afloramientos del Devónico Superior. (Leyenda en Fig. 6).

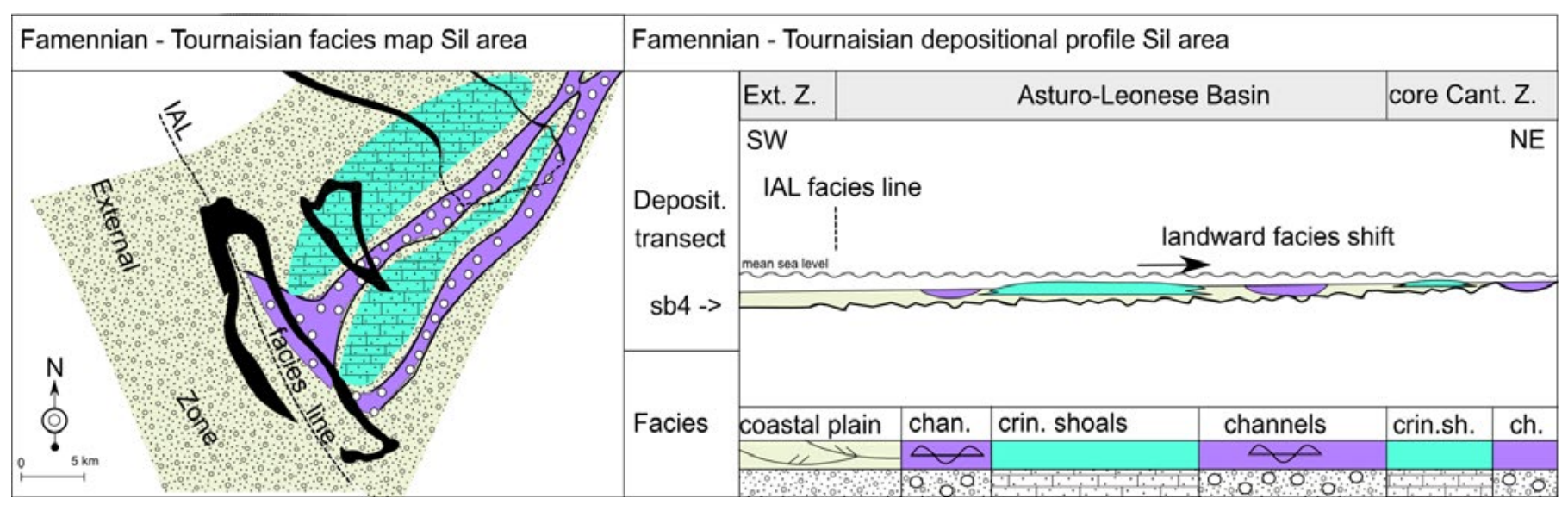

Figure 25. Famennian-Tournaisian palaeogeography of the Sil area. The black silhouettes correspond to the outcrops of the Nocedo, Fueyo and Ermita formations. For legend see Figure 6.

Figura 25. Paleogeografía del área del Sil durante el Famenniense-Tournaisiense. En línea negra se resaltan los afloramientos del Devónico Superior. (Leyenda en Fig. 6). 
Frasnian strata. Gradual uplift of the land area in the northeast resulted in a shoreline regression and the migration of the shallow marine coastal area and the hinge line in a seaward direction.

Lower Famennian: Early Famennian deposition was controlled by regional tectonic activity. Areas of tectonic elevation and erosion resulted in an increase in sediment supply to the basin, and subsidence of adjacent areas generated the accommodation space for the sequences. The core of the Cantabrian Zone, and the proximal parts of the Asturo-Leonese Basin were uplifted and eroded (Fig. 24). The hinge line separated the uplifted area in the core of the Cantabrian Zone, from the area of subsidence. Its location shifted from a Frasnian position in the northeast (in present day co-ordinates), to a Famennian location in the outermost part of the Asturo-Leonese Basin close to the Intra Asturo-Leonese facies line (IAL facies line). The extension of the uplifted area caused a depositional shift towards the External Zone in the southwest. The sedimentary wedge contains a storm-bedded shale-sandstone succession with slumped horizons and soft-sediment deformed sandstone strata. Close to the IAL facies line a shoreface environment is assumed. The basinward facies shift caused the shallowing and coarsening upward sequence in the External Zone from the transitional storm-bedded shale-sandstone succession to the cross-bedded shoreface sandstone at the top of the sequence. Locally coarse conglomerates channels from the uplifted land area in the northeast entered the basin. On the inner side of the IAL facies line, the subsequent Famennian uplift and erosion probably removed the Lower Famennian sedimentological record.

Upper Famennian-Lower Tournaisian: Sb4, the Upper Devonian Unconformity, marks the Late Famennian-early Tournaisian depositional change from a clastic wedge area in the outermost part of the Cantabrian Zone, towards an extensive shallow marine area of the former sub-aerially exposed grounds in the northeast. A thin veneer of fluvial-tidal pebbly sandstone, conglomerate channels and carbonate shoals spread over the emerged northern part of the Asturo-Leonese Basin and the central parts of the Cantabrian Zone (Fig. 25). There was little accommodation space because of missing subsidence, and shifted sediment loads were constantly reworked, which resulted in winnowing and the formation of a lag sediment. A condensed succession was deposited with internal erosion surfaces, hardground and mineralisation surfaces. From cross-bedded sets of pebbly sandstone beds a dominant southwestern transport direction can be inferred. Therefore, it is assumed that detritus derived from the eroded uplifted area in the northeast, and was transported by the channel system into the basin. Bathymetrical centre and/or depocenter in the Sil area were no longer connected to the IAL facies line and/or the External Zone, and the influence of these pre-Variscan palaeographic features declined.

\section{Conclusions}

Sil area: The following conclusions can be drawn from this study:

- The southwestern limb of the Vega de los Viejos syncline contains the most complete and thickest Upper Devonian successions of the Sil area and can be correlated with sequences $A, C$ and $D$ in the Bernesga area. Sequence $B$ is not exposed. The Upper Devonian sections of Meroy and La Cueta are located closer to the uplifted area of the central part of the Cantabrian Zone. The sections are thinner and less complete.

- The entire Upper Devonian succession below the Upper Devonian Unconformity sb4 of the sections Meroy and La Cueta can be interpreted as a single sequence.

- From 1) the stratigraphic position of the sequence directly on top of the reefal limestone of the Portilla Formation, 2) the facies stack, and 3) the Frasnian fossil content, it becomes plausible to correlate the succession below the Upper Devonian Unconformity with sequence $A$ in the Bernesga area.

- The overlying thin, max. $26 \mathrm{~m}$ thick package of pebbly sandstone and conglomerate channel-fiII above sb4 constitute the top of the Upper Devonian succession in the Sil area and can be correlated with the condensed Famennian-Tournaisian Llombera Beds. Together with the overlying approximately $4 \mathrm{~m}$ thick succession of sandy crinoidal limestone, attributed to the $\mathrm{Ba}$ leas Formation, they constitute sequence $D$.

- The Upper Devonian sequence boundaries manifest in several ways: proximal high-relief surfaces associated with incised valleys and downcutting channels, sharp flat surfaces, mineralization surfaces, but subtle boundaries of correlative conformities in distal depositional areas also occur. The sedimentological imprints of the sequence boundaries change across the depositional profile and are mainly controlled by the palaeogeographic position in the basin.

- The Frasnian is characterised by subtle tectonic activity and extreme greenhouse conditions, and as a consequence, sea-level fluctuations had a low amplitude, resulting in gradually shifting facies belts and depositional transitions as recorded in sequence $A$.

- Increased Famennian tectonic activity divided the basin into areas of uplift and erosion, and of subsidence and sedimentation. Differential tectonic movements are suggested as the major factor controlling the Famennian accommodation space of the Asturo-Leonese Basin and the erosive boundary surfaces in the proximal parts of the Upper Devonian Basin.

Bernesga area: From this study a remarkable similarity appears between the Upper Devonian de- 
velopment of the Sil area and the described Upper Devonian development of the Bernesga area in Van Loevezijn and Van Loevezijn Peña (2017), and Van Loevezijn (2020):

- The Lower Frasnian succession (sequence A) extended far into the inner part of the Asturo-Leonese Basin.

- Sequence A sediments were deposited on a gradual depositional slope profile, with a land area in the northeast, a sandy coastal environment in the core area and an offshore shale environment in the outer area.

- During the late Frasnian-early Famennian the shallow marine shelf of the outer area transformed into a zone of rapid subsidence, the External Zone, separated by the IAL facies line from the northern area of uplift and erosion.

- Sequence $C$ of the early Famennian age is only found in the External Zone, and contains a thick, storm-bedded succession.

- In both areas the Upper Devonian clastic wedges are overlain by a condensed sheet of conglomeratic sandstone and coarse-grained limestone of late Famennian-earlyTournaisian age (sequence D).

However, there are also differences between the Upper Devonian development of the Sil and Bernesga areas:

- Sequence A of the Sil area contains a sandy and coarse-grained development. The succession in the Bernesga area is finer-grained.

- The Molino limestone in the Sil area is intercalated in the lower half of sequence A. In the Bernesga the limestone occurs higher in the sequence.

- Sequence D of the Sil area contains a max. $26 \mathrm{~m}$ thick succession of coarse sand and conglomerates; in the Bernesga area the coarse succession is usually significantly thinner (between 5 and $10 \mathrm{~m}$ ).

Coastal ranges: The following conclusions can be drawn from this study:

- The basal and thickest part of the Piñeres Sandstones in the studied sections of the coastal range of Asturias can be correlated to sequence $A$.

- The overlying limestone unit of the Carranques section has been considered to be late Frasnian or slightly older, and therefore falls within sequence $B$ of the Upper Devonian sequential scheme.

- At the Playa de Boletos and Gargantera beaches a sharp erosive contact separates sequence $A$ from an overlying thin-bedded shale-sandstone alternation. These shale-sandstone rhythmites are tentatively correlated with the tempestite succession of sequence $B$ in the Bernesga area.

- In the coastal range the overlying Llombera Beds are replaced by a well-bedded bioclastic limestone succession attributed to the Candamo Formation.

Central Asturias: The following conclusions can be drawn from this study:
- The Upper Devonian lithofacies and thickness distribution of the Sil successions correspond in general with the Upper Devonian development of central Asturias, with coarse-grained quartz arenites, conglomerates, and a rapid proximal thinning towards the core of the Cantabrian Zone (Martínez-Álvarez et al., 1975; Pello Muñiz, J., 1976, and our own observations).

\section{Acknowledgements}

Reviews by J.R. Colmenero and R. Gonzalo have much improved the manuscript and prompted some additional field work. J.R. Colmenero also provided the Spanish translations.

\section{References}

Alonso, J. L. L., Marcos, A. and Suárez, A. 2009. Paleogeographic inversion resulting from large out of sequence breaching thrusts: the León Fault (Cantabrian Zone, NW Spain. A new picture of the external Variscan Thrust Belt in the lbero-Armorican Arc. Geologica Acta, 7 (4), 451-473.

Barrois, C. 1882. Recherches sur les terrains anciens des Asturias et de la Galice. Mémoires de la Société Géologique du Nord, 2 (1), 1-630.

Brouwer A. 1964. Deux facies dans le Dévonien des Montagnes Cantabriques Méridionales. Brevoria Geologica Asturica, 4, 3-10.

Burchette, T. P. and Wright, P. 1992. Carbonate ramp depositional systems. Sedimentary Geology, 79, 3-57.

Catuneanu, O. 2017. Sequence stratigraphy: guideline for a standard methodology. In: Montenari, M. (ed.), Advances in sequence stratigraphy. Stratigraphy and Timescales, 2, 1-57.

Comte, P. 1959. Recherches sur le terrains ancients de la cordillera Cantabrique. Memorias del Instituto Geológico y Minero de España, 60, 1-440.

Csato, I. and Catuneanu, O. 2012. Systems tract successions under variable climatic and tectonic regimes: A quantitative approach. Stratigraphy, 9 (2), 109-130.

Dott, R.H. 1964. Wacke, Graywacke and matrix-what approach to immature sandstone classification? Journal of Sedimentary Petrology, 34, 625-632.

Dott, R. H. and Burgeois, J. 1982. Hummocky stratification: significance of its variable bedding sequences. Geological Society of America, 93, 663-680.

Dunham, R.J. 1962. Classification of carbonate rocks according to depositional texture. In: Ham, W. (ed.), Classification of carbonate rocks. American Association of Petroleum Geologists, Memoirs, 1, 108-122.

Embry A. F. and Klovan, E. J. 1972. Absolute water depth limits of Late Devonian palaeoecological zones. Geologische Rundschau, 61, 672-686.

Fernández, L. P., Fernández-Martínez, E., Méndez-Bedía, I., Rodríguez, S. and García-Ramos, J. 
C., 1995. Devonian and Carboniferous reefal facies from the Cantabrian Zone (NW Spain). VII International Symposium on Fossil Cnidaria and Porifera, Field trip A, Guide book, Madrid, 72 pp.

Fernández, L. P., García-Alcalde, J. L. and Alonso, J. L. 2021. La Formación Ermita en el sinclinal de Vega de los Viejos. Geotemas, 18, 150-153.

Fernández-Martínez, E., Fernández, L. P., Méndez-Bedia, I. and Soto, F. 2008. Episodios arrecifales en el Devónico de la región del Cabo de Peñas (Asturias). Guía de campo

(Excursión B). Museo del Jurásico de Asturias (MUJA), Colunga, $44 \mathrm{pp}$.

Flügel, E. 2004. Microfacies of carbonate rocks. Springer-Verlag, Berlin-Heidelberg, 1-976.

Frankenfeld, H. 1984. Deckenbewegungen im Namur der östlichen Kantabrischen Gebirges und die damit verbundenen Vorstellungen über die Paläogeographie der Namur- und prä- Namur-Schichen. Zeitschrift der Deutschen Gesellschaft für Geowissenschaften, 135, 223-241.

García-Alcalde, J. L. 1978. Información complementaria. In: Rodríguez Fernández, L. R (ed), Memoria del mapa geológico de España escala 1:50000, 76 (Pola de Somiedo) - segunda serie. Instituto Geológico y Minero de España primera edición, 56 pp.

García-López, S. 1976. La Caliza de Candás en la zona de Luanco (Asturias) y su contenido en conodontos. Trabajos de Geología de la Universidad de Oviedo, 8, 173-185.

García-López, S. 1987. Los conodontos y su aplicación al estudio de las divisions

cronostratigráficas mayores del Devónico Asturleonés (España). Publicaciones Especiales del Boletín Geológico y Minero de España, 1-112.

García-López, S. and Sanz-López, J. 2002a. Devonian to Lower Carboniferous conodont biostratigraphy of the Bernesga Valley section (Cantabrian Zone, NW Spain). In: García- López, S. and Bastida, F. (eds), Paleozoic conodonts from northern Spain. Cuadernos del Museo Geominero, 1, Madrid, 163205.

García-López, S. and Sanz-López, J. 2002b. The Palaeozoic succession and conodont biostratigraphy of the section between Cape Peñas and Cape Torres (Cantabrian coast NW Spain). In: García-Lopez, S. and Bastida, F. (eds), Paleozoic conodonts from northern Spain. Cuadernos del Museo Geominero, 1, Madrid, 126-156.

García-Ramos, J. C. and Colmenero, J. R. 1981. Evolución sedimentaria y paleogeogáfica durante el Devónico en la Cordillera Cantábrica. Program. Int. Corr. Geol. (2a parte). Real Academia de Ciencias Exactas, Físicas y Naturales, Segunda Parte, 61-71.

Gosh, P., Sarkar, S. and Maulik, P. 2006. Sedimentology of a muddy alluvial deposit: Triassic Denwa Formation, India. Sedimentary Geology 191, 3-36.

Gutiérrez-Alonso, G.., Fernández-Suárez, J., and Weil, A. B. 2004. Orocline triggered lithospheric delam- ination? In: Susseman, A. J. and Weil, A. B. (eds), Paleomagnetic and structural analysis of Orogenic curvature. Special paper of the Geological Society of America, 383, 121-123.

Herrero-Alonso, D., Tarriño-Vinagre, A., Neira-Campos, A. and Fuertes-Prieto, N. 2016. Vegamián Formation: A new raw-material supply source in the Cantabrian Mountains (NW Spain) during prehistory. Journal of Lithic Studies, 3 (2), 1-21.

Julivert, M. 1971. Décollment tectonics in the Hercynian Cordillera of NW Spain. American Journal of Science., 270, 1-29.

Keller, M., Bahlburg, H. and Reuther, C.D. 2008. The transition from passive to active margin sedimentation in the Cantabrian Mountains, Northern Spain: Devonian or Carboniferous? Tectonophysics, 461, 414-427.

Kullmann, J. and Schönenberg, R. 1975. Geodynamische und palökologische Entwicklung im Kantabrischen Variszikum (Nordspanien). Ein interdiziplinäres Arbeitskonzept. Neues Jahrbuch für Geologie und Paläontologie Monatshefte, 3, 151166.

Lotze, F. 1945. Zur Gliederung de Varisziden in der Iberischen Meseta. Geotektonische Forschungen, 6, 7892.

Marcos, A. and Pulgar, F. J. 1982. An approach to the tectonostratigraphic evolution of Cantabrian thrusts and fold belt, Variscan Cordillera of NW Spain. Neues Jahrbuch für Geologie und Paleontologie Abhandlungen, 163, 256-260.

Martín-Merino, G, Fernández, L. P., Colmenero, J. R. and Bahamonde, J. R. 2014. Mass-transport deposits in a Variscan wedge-top foreland basin (Pisuerga area, Cantabrian Zone, NW Spain). Marine Geology, 356, 71-87.

Martínez Álvarez, J. A., Gutiérrez Claverol, M. and Torres Alonso, M. (1975). Memoria. Mapa Geológico de España escala 1:50000, 28 (Grado) segunda serie. Instituto Geologico y Minero de España, primera edition, $49 \mathrm{pp}$.

Matte, P. 1991 Accretionary history and crustal evolution of the Variscan belt in western Europe. Tectonophysics, 196 (3-4), 309-337.

Myrow, P.M. and Southard, J.B. 1996. Tempestite deposition. Journal of Sedimentary Research, 66 (5), 875-887.

Nichols, G. 2009. Sedimentology and Stratigraphysecond edition. Wiley-Blackwell, Chichester (UK), $419 \mathrm{pp}$.

Pastor-Galán, D., Gutiérrez-Alonso, G., Fernández-Suárez, J., Murphy, J.B. and Nieto, F. 2013. Tectonic evolution of NW lberia during the Paleozoic inferred from the geochemical record of detrital rocks in the Cantabrian Zone. Lithos, 182-183, 211-228.

Pello Muñiz, J. 1976. Memoria. Mapa Geológico de España escala 1:5000, 52 (Proaza) segunda serie. Instituto Geológico y Minero de España, primera edition, $53 \mathrm{pp}$. 
Peréz-Estaún, A., Bastida, F., Alonso, J. L., Marquínez, J., Aller, J., Álvarez-Marrón, J., Marcos, J., and Pulgar, J. A. 1988. A thin-skinned tectonics model for an arcuate fold and thrust beld: the Cantabrian Zone (Variscan Ibero-Armorican Arc). Tectonics, 7, 517-537.

Radig, F. 1961. Ordovicium/Silurium und die Frage praevariszischer Faltungen in Nord Spanien. Geologische Rundschau, 52, 346-457.

Raven, J G.M. 1983. Conodont biostratigraphy and depositional history of the Middle Devonian to Lower Carboniferous in the Cantabrian Zone (Cantabrian Mountains, Spain). Leidse Geologische Mededelingen, 52, 265-339.

Reineck, H.E. and Singh, J.B. 1975. Depositional sedimentary environments. Springer, Berlin, $439 \mathrm{pp}$.

Reinson, G.E. 1979. Facies models 14, Barrier islands. Geoscience Canada, 6 (2), 51-68.

Remane, A and Schlieger, C. 1971. Biology of Brackish Water. John Whiley and Sons, New York, 372 pp.

Rodríguez-Fernández, L.R. 1979. Memoria. Mapa Geológico de España escala 1:50000, 76 (Pola de Somiedo) segunda serie. Instituto Geológico y Minero de España primera edición, 51 pp.

Sánchez de la Torre, L. 1977. Guía de las sesiones de campo. Formaciones detríticas y carbonatadas del Devónico Medio y Superior de la Cordillera Cantábrica. VIII Congreso Nacional de Sedimentología. Oviedo-León, 1977. Publicaciones del Departamento de Estratigrafía y Geología Histórica de la Universidad de Oviedo, $54 \mathrm{pp}$.

Sánchez de la Torre, L., Colmenero, J.R., Suárez de Centi, C. 1976. Serie de la arenisca del Devónico Superior en la Paya de la Gargantera. Trabajos de Geología, 8, 187-201.

Schlager, W. 2005. Carbonate Sedimentology and Sequence Stratigraphy. Society for Sedimentary Geology, Concepts in Sedimentology and Paleontolo$g y, 8,200 \mathrm{pp}$.

Sjerp, N. 1967. The geology of the San Isidro-Porma area (Cantabrian Mountains, Spain). Leidse Geologische Mededelingen, 38, 55-128.

Stampfli, G.M., Hochard, C., Vérard, C., Wilhem, C. and Von Raumer, J. 2013. The formation of Pangea. Tectonophysics, 593, 1-19.

Truyols, J., Arbizu, M., García-Alcalde, J. L., GarcíaLópez, S., Méndez-Bedia, I., Soto, F. and Truyols Massoni, M. 1990. The Asturian-Leonese Domain (Cantabrian Zone). In: Dallmeyer, R. D. and Martínez García, E. (eds), Pre-Mesozoic geology of Iberia, 10-19, Berlin-Heidelberg (Springer).

Van Adrichem Bogaert, H.A. 1967. Devonian and Lower Carboniferous conodonts of the Cantabrian Mountains (Spain) and their stratigraphic application. Leidse Geologische Mededelingen, 39, 1-129.
Van den Berg, J. H., Boersma, J. R. and Van Gelder, A. 2007. Diagnostic sedimentary structures of the fluvial-tidal transition zone - Evidence from deposits of the Rhine and Meuse. Netherland Journal of Geoscience, 86 (3), 287-306.

Van den Bosch, W J. 1969. Geology of the Luna-Sil region, Cantabrian Mountains (NW Spain). Leidse Geologische Mededelingen, 44, 137-225.

Van Loevezijn, G.B.S. 1986. Stratigraphy and facies of the Nocedo, Fueyo and Ermita formations (Upper Devonian to lowermost Carboniferous) in León, $\mathrm{N}$ Spain. Scripta Geologica, 81, 1-116.

Van Loevezijn, G.B.S., 2020. Forebulge dynamics and sedimentary response of an initial Variscan foreland basin; the Upper Devonian of the southern Cantabrian Mountains, N Spain. Zeitschrift der Deutschen Gesellschaft für Geowissenschaften, 171 (3), 249-276.

Van Loevezijn, G.B.S. and Raven, J.G.M. 1984. The Upper Devonian of the Somiedo area (Cantabrian Mountains, northwestern Spain). Neues Jahrbuch für Geologie und Paläontologie, Monatsheften, 5, 279-290.

Van Loevezijn, G B.S. and Raven, J.G.M. 2017. Frasnian carbonate shoals and sequence stratigraphy of the Upper Devonian series from the southern Cantabrian Mountains, northern Spain. Boletín Geológico y Minero de España, 128 (4), 931-961.

Van Loevezijn, G.B.S. and Raven, J.G.M. 2020. Facies patterns and depositional processes of two Frasnian mixed siliciclastic-carbonate systems in the Cantabrian Mountains, NW Spain. Geologos, 26, 1-23.

Van Loevezijn, G.B.S. and Van Loevezijn Peña, A.L.M. 2017. Facies cycles and sequences in the Upper Devonian of the Bernesga area. Zeitschrift der Deutschen Gesellschaft für Geowissenschaften, 168 (3), 313-339.

Vázquez, D.N. 1978. Memoria. Mapa geológico de España escala 1:50000, 101 (Villablino), segunda serie. Instituto Geológico y Minero de España primera edición, $56 \mathrm{pp}$.

Vleeshouwer, D., Crucifix, M., Bonceur, N. and Claeys, P. 2014. The impact of astronomical forcing on the Late Devonian greenhouse climate. Global and Planetary Change, 120, 65-80.

Wagner, R.H., Winkler Prins, C.F. and Riding, R.E. 1971. Lithostratigraphic units of the lower part of the Carboniferous in northern León, Spain. Trabajos de Geología, 4, 603-663.

Walker, R.G. and Plint, A.G. 1992. Wave and storm shaIlow marine systems. In: Walker, R.G. and James, N.P. (eds), Facies Models: Response to Sea Level Change. Geological Association of Canada, Geotext, 1, 219-238.

Recibido: julio 2019

Revisado: noviembre 2019

Aceptado: enero 2020

Publicado: diciembre 2021 